\title{
Fragment Assembly Approach Based on Graph/Network Theory with Quantum Chemistry Verifications for Assigning Multidimensional NMR Signals in Metabolite Mixtures
}

Kengo Ito, ${ }^{\dagger,}$ Yu Tsutsumi, ${ }^{\S}$ Yasuhiro Date, ${ }^{\dagger, \ddagger}$ and Jun Kikuchi $*, \dagger, *, \#$

${ }^{\dagger}$ Graduate School of Medical Life Science, Yokohama City University, 1-7-29 Suehirocho, Tsurumi-ku, Yokohama 230-0045, Japan

${ }^{*}$ RIKEN Center for Sustainable Resource Science, 1-7-22 Suehiro-cho, Tsurumi-ku, Yokohama 235-0045, Japan

${ }^{\S}$ Bruker BioSpin K.K., 3-9 Moriya-cho, Kanagawa-ku, Yokohama 221-0022, Japan

\# Graduate School of Bioagricultural Sciences and School of Agricultural Sciences, Nagoya University, 1 Furo-cho, Chikusa-ku, Nagoya 464-8601, Japan 


\section{Table of Contents}

1. Supplementary Methods

S3-S8

2. Supplementary Results and Discussion

\section{Tables and Figures}

1) Supplementary Figure S1. The intensity of the NUS ${ }^{13} \mathrm{C}-{ }^{13} \mathrm{C}$ COSY spectrum is compared with a conventional spectrum measured using a standard mixture.

S10

2) Supplementary Figure S2. Multidimensional NMR spectra of the standard mixture.

S11

3) Supplementary Figure S3. Fragment assembly approach using the correlation signals of components in the standard mixture.

S12

4) Supplementary Figure S4. COLMAR analysis using HSQC signals in C. brachypus.

S13

5) Supplementary Figure S5. Fragment assembly approach using the correlation signals of L-glutamate in $C$. brachypus.

S14

6) Supplementary Figure S6. Alignment of NMR signals in the mixture of 12 standards for automatic chain assignment.

S15

7) Supplementary Figure S7. Each processing step of the automatic chain assignment algorithm.

S16

8) Supplementary Figure S8. Multidimensional NMR spectra of C. brachypus.

S17

9) Supplementary Table S1. Pulse sequences, parameters, and conditions of NMR measurements.

S18

10) Supplementary Table S2. Assignments for the standard mixture by database searching and automatic chain assignment.

S19

11) Supplementary Table S3. The annotation list for ${ }^{1} \mathrm{H}-{ }^{13} \mathrm{C}$ HSQC and HSQC-TOCSY of C. brachypus by database searching and evaluation of the correlation signals.

S20-S22

12) Supplementary Table S4. The annotation list for ${ }^{13} \mathrm{C}-{ }^{13} \mathrm{C}$ TOCSY of $C$. brachypus by database searching and evaluation of the correlation signals.

S23-S31

13) Supplementary Table S5. List of calculated RMSD values between the experimental and theoretical chemical shifts of compounds in C. brachypus.

S33

14) Supplementary Table S6. Experimental solubility data for 18 compounds in water.

S34

15) Supplementary Table S7. List of calculated RMSD values between the experimental and theoretical chemical shifts of some compounds to test the effect of water.

S35

16) Supplementary Table S8. The annotation list for Q-C correlations of C. brachypus by database searching. 


\section{Supplementary Methods}

\section{Sample Preparation}

Twelve ${ }^{13} \mathrm{C}$-labeled standard samples (formic acid, pyruvate, glycerol, $\alpha$-ketobutyric acid, L-serine, fumaric acid, succinic acid, D-ribose, D-xylose, D-galactose, D-fructose, and D-glucose; ${ }^{13} \mathrm{C}$ ratio, $97 \%-99 \%$ ) were mixed and the final concentration was adjusted to $1 \mathrm{mM}$ in $1 \mathrm{~mL} \mathrm{KPi} / \mathrm{D}_{2} \mathrm{O}$ buffer with sodium 2,2-dimethyl-2-silapentane-5-sulfonate (DSS). The supernatant was placed in a $5 \mathrm{~mm}$ NMR tube.

C. brachypus, a green alga, was grown and labeled with a ${ }^{13} \mathrm{CO}_{2}$ gas mixture $(99 \%$ purity, Spectra Gases Inc., NJ, USA, air composition with 500 ppm $\mathrm{CO}_{2}$ ) in $1 \mathrm{~L}$ marine flasks (Biomedical Science Co., Ltd., Tokyo, Japan) during initial growth, followed by a $60 \mathrm{~L}$ water tank in the main growth stage. A silicon plug (Shin-Etsu Polymer Co., Ltd., Tokyo, Japan) was placed in the marine flask and a plastic cover was placed on the water tank to maintain certain conditions (water temperature: $\sim 25^{\circ} \mathrm{C}$, ammonia and nitrous acid concentration: $0 \mathrm{ppm}, \mathrm{pH}$ : $\sim 8.5$, and salinity: $\sim 3 \%$ ). $\mathrm{A}^{13} \mathrm{CO}_{2}$ gas mixture flowed continuously into the flasks and water tank, and blue light-emitting diodes (LED) and fluorescent lamps were used to allow photosynthesis (light, 16 h; dark, 8 h). A filtration device (EHEIM Co., Ltd., Chiba, Japan) was fitted to the water tank. The seaweed was grown from 1 to 2 months under these conditions. The samples were frozen and stored at $-80^{\circ} \mathrm{C}$. After freeze-drying, each sample was milled with a Shake Master (Biomedical Science Co., Ltd., Tokyo, Japan). Isotope ratio mass spectrometry (IR-MS) analysis was performed on IsoPrime 100 (Jasco International Co., Ltd., Tokyo, Japan) in combination with an elemental analyzer (Vario MICRO cube) in CN mode, and the isotopic ratios of carbon and nitrogen in the samples were measured using $\mathrm{CO}_{2}$ and $\mathrm{N}_{2}$ gases with the IR-MS instrument. A crushed sample $\left({ }^{13} \mathrm{C}\right.$ ratio $=$ $36.5 \%, 76.5 \mathrm{mg}$ ) was added to $1 \mathrm{~mL}$ methanol and incubated at $50{ }^{\circ} \mathrm{C}(20 \mathrm{~min}, 1400 \mathrm{rpm})$. The residue was collected after centrifugation at $24{ }^{\circ} \mathrm{C}$ (10 min, $15000 \mathrm{rpm}$ ), and redried in an evaporator (Tokyo Rikakikai Co., Ltd., Tokyo, Japan). The treatment step was repeated three times to evaluate only the water-soluble fraction. The residue sample $(42 \mathrm{mg})$ was suspended in $1 \mathrm{~mL}$ phosphate buffer solution $\left(0.1 \mathrm{M} \mathrm{K}_{2} \mathrm{HPO}_{4} / \mathrm{KH}_{2} \mathrm{PO}_{4}\right.$; $\mathrm{pH}$ 7.0) containing 90\% deuterium oxide and $1 \mathrm{mM}$ DSS as an internal standard for NMR spectroscopy. The water-soluble fraction was extracted at $70{ }^{\circ} \mathrm{C}(20 \mathrm{~min}, 1400 \mathrm{rpm})$, and the supernatant was collected after centrifugation at $24{ }^{\circ} \mathrm{C}(10 \mathrm{~min}, 15000 \mathrm{rpm})$. NMR samples of seaweed were prepared in essentially the same way as in previous studies. ${ }^{1,2}$

\section{NMR Measurements}

Spectra were acquired at $298 \mathrm{~K}$ on a 500, 600, or $700 \mathrm{MHz}$ Bruker Biospin NMR instrument. Two-dimensional (2D) ${ }^{1} \mathrm{H}-{ }^{13} \mathrm{C}$ HSQC-TOCSY and ${ }^{1} \mathrm{H}-{ }^{13} \mathrm{C}$ HSQC were used for the detection of $\mathrm{H}-\mathrm{C}$ correlations. ${ }^{1} \mathrm{H}-{ }^{1} \mathrm{H}$ TOCSY was used for the detection of $\mathrm{H}-\mathrm{H}$ correlations. ${ }^{13} \mathrm{C}-{ }^{13} \mathrm{C} \mathrm{COSY}$ and ${ }^{13} \mathrm{C}-{ }^{13} \mathrm{C}$ TOCSY were used for the detection of $\mathrm{C}-\mathrm{C}$ correlations. The correlations with quaternary carbon $(\mathrm{Q}-\mathrm{C})$ were weak peaks. Therefore, these peaks were detected by covariance processing using ${ }^{13} \mathrm{C}-{ }^{13} \mathrm{C}$ TOCSY. These pulse programs of multidimensional NMR were used for comprehensive construction of the frameworks of the chemical structures. Three-dimensional HCCH-COSY NMR was applied for the detection of $\mathrm{C}-\mathrm{H}$ and $\mathrm{C}-\mathrm{C}$ correlations. Nonuniform sampling (NUS) ${ }^{3,4}$ was applied to each pulse program to shorten the experimental time and increase the resolution of deployment direction in the multidimensional NMR measurements. However, a loss of reproducibility due to vanishing peaks has been reported. ${ }^{5}$ In recent years, the possibility of quantitative measurement using NUS has been suggested, ${ }^{6}$ and quantitative statistical analysis allows the use of data from NUS spectra. ${ }^{7}$ Furthermore, focusing on protein NMR, the effectiveness of the NUS method has been shown. ${ }^{8,9}$ The $^{2}$ first step of the NMR measurements in this study was to verify the usefulness of the NUS method. Table S1 shows the major parameters of the pulse programs used in this study. 


\section{Spectral Data Pretreatment}

All NMR spectra were processed with TopSpin 3.2 software (https://www.bruker.com/jp.html) for phase correction, calibration, and reconstruction of NUS spectra. Discrete data of the NUS spectra were reconstructed using iteratively reweighted least squares (IRLS) as a compressed sensing (CS) algorithm. ${ }^{5}$ The validity of the reconstructed NUS spectra was confirmed by comparison with conventional spectra using the skyline projection data of the ${ }^{13} \mathrm{C}-{ }^{13} \mathrm{C}$ COSY spectra. Linearity was shown between the NUS and conventional spectra by superposition and regression analysis of intensity, and no lost peaks were observed (Figure S1). The peak maxima of HSQC, HSQC-TOCSY, COSY, and TOCSY were picked automatically using the "Auto-Pick All" function in the TopSpin 3.2 software. The overlapped peaks that could not be picked automatically were picked manually. The ${ }^{1} \mathrm{H}$ peaks were aligned using picked data from HSQC $\left(\mathrm{F} 2 ;{ }^{1} \mathrm{H}\right)$ and HSQC-TOCSY $\left(\mathrm{F} 2 ;{ }^{1} \mathrm{H}\right)$, and the ${ }^{13} \mathrm{C}$ peaks were aligned using picked data from HSQC $\left(\mathrm{F} 1 ;{ }^{13} \mathrm{C}\right)$, HSQC-TOCSY $\left(\mathrm{F} 1 ;{ }^{13} \mathrm{C}\right)$, COSY $\left(\mathrm{F} 2 ;{ }^{13} \mathrm{C}, \mathrm{F} 1 ;{ }^{13} \mathrm{C}\right)$, and TOCSY $\left(\mathrm{F} 2 ;{ }^{13} \mathrm{C}, \mathrm{F} 1 ;{ }^{13} \mathrm{C}\right)$. The displacement of the peaks of a compound in the same and different experiments was considered according to probability distribution, and alignment was achieved by adjusting the peaks to the center of distribution when peaks were in the probability distribution (Figure S6). The density function in R was used for alignment by the kernel density estimation. Here, the smoothing bandwidth parameter was rough in the entire range, except the saccharide area, where it was fine. If this parameter is too rough, peaks are aligned with other compounds, whereas if it is too fine, the peaks cannot be aligned sufficiently. Therefore, the parameters should be chosen by checking the alignment result. In addition, HSQC spectra were projected on the F2 and F1 axes to create $1 \mathrm{D}{ }^{1} \mathrm{H}$ and ${ }^{13} \mathrm{C}$ data. The picked peaks were also aligned by adjusting the peaks to the peak maxima of the projection data. Finally, both alignment methods were used semi-automatically. These alignments were performed in order to optimize the automatic chain assignment.

\section{Chain Assignment with an Automatic Algorithm Based on Network Theory}

In this study, the R language (https://www.r-project.org/) was used to program the network algorithm using the $\mathrm{H}-\mathrm{H}$, $\mathrm{H}-\mathrm{C}$, and $\mathrm{C}-\mathrm{C}$ bonding information of the compounds. The aim of using automatic chain assignment is the simplification of manual chain assignment for complex mixtures. This was an automatic algorithm for chain assignment based on network theory, allowing the assignment of a chemical backbone using ${ }^{1} \mathrm{H}-{ }^{13} \mathrm{C}$ HSQC and ${ }^{1} \mathrm{H}-{ }^{13} \mathrm{C}$ HSQC-TOCSY for $\mathrm{C}-\mathrm{H}$ correlations, ${ }^{1} \mathrm{H}-{ }^{1} \mathrm{H}$ COSY or ${ }^{1} \mathrm{H}-{ }^{1} \mathrm{H}$ TOCSY for $\mathrm{H}-\mathrm{H}$ correlations, and ${ }^{13} \mathrm{C}-{ }^{13} \mathrm{C}$ COSY or ${ }^{13} \mathrm{C}-$

${ }^{13} \mathrm{C}$ TOCSY for $\mathrm{C}-\mathrm{C}$ correlations. A chemical backbone is constructed to connect the $\mathrm{C}-\mathrm{H}$ fragments and quaternary carbons. The peaks of pure components and/or components with the same partial structures in the mixture were clustered by a network of dimensional correlation peaks. The algorithm without 2D homonuclear NMR measurement data was also used for assignment because many peaks could not be detected in the ${ }^{1} \mathrm{H}-{ }^{1} \mathrm{H}$ TOCSY of C. brachypus.

\section{Detail of Automatic Chain Assignment Algorithm Step}

1. Construct the undirected graph $\mathrm{G}=<\mathrm{V}, \mathrm{E}>$ of HSQC-TOCSY by matched conditions, where the node set is $\mathrm{V}=\left\{\mathrm{v}_{1}, \mathrm{v}_{2}, \mathrm{v}_{2}^{\prime}, \mathrm{v}_{3}^{\prime}\right\}$ and the edge set is $\mathrm{E}=\left\{\mathrm{v}_{1} \mathrm{v}_{2}, \mathrm{v}_{2}^{\prime} \mathrm{v}_{3}^{\prime}\right\}$. The node $\mathrm{v}$ denotes each peak that has a chemical shift, and the edge vv denotes the connectivity of two peaks. Create all patterns of node set V, which have 4 peaks; if the conditions $\boldsymbol{a}$ and $\boldsymbol{b}$ are matched, a network in the HSQC-TOCSY spectrum is created, which is graph G.

a. $\mathrm{v}_{1}=\mathrm{v}_{2}=\mathrm{v}_{2}^{\prime}\left(\right.$ on ${ }^{1} \mathrm{H}$ chemical shift axis)

b. $v_{2}=v_{2}^{\prime}=v_{3}^{\prime}$ (on ${ }^{13} \mathrm{C}$ chemical shift axis) 
2. Determine the undirected graph $\mathrm{G}$ by matched conditions using the correlation signals, where the edge set of ${ }^{1} \mathrm{H}-{ }^{1} \mathrm{H} \mathrm{COSY}$ and/or ${ }^{1} \mathrm{H}-{ }^{1} \mathrm{H}$ TOCSY is $\mathrm{E}_{\mathrm{H}}=\left\{\mathrm{H}_{1} \mathrm{H}_{2}\right\}$, the edge set of ${ }^{13} \mathrm{C} \mathrm{COSY}$ and/or ${ }^{13} \mathrm{C}$ TOCSY is $\mathrm{E}_{\mathrm{C}}=\left\{\mathrm{ClC}_{2}\right\}$, the node set of HSQC is $\mathrm{V}_{\mathrm{CH}}=\{\mathrm{CH} 1$, $\mathrm{CH} 2\}$, and the diagonal node set of HSQC-TOCSY is $\mathrm{V}_{1}=\left\{\mathrm{v}_{1}, \mathrm{v}_{3}\right\}$. The certainty of the network in the HSQC-TOCSY spectrum as graph G is confirmed by conditions $\boldsymbol{a}$ and $\boldsymbol{b}$, which can evaluate the certainty of the correlation signals. If condition $\boldsymbol{c}$ is mismatched, graph $\mathrm{G}$ has a correlation signal of another compound. Here, the incorrect graph $\mathrm{G}$ is removed.

a. $\mathrm{E}_{\mathrm{H}} \subset \mathrm{E}$ (on ${ }^{1} \mathrm{H}$ chemical shift axis)

b. $\mathrm{E}_{\mathrm{C}} \subset \mathrm{E}$ (on ${ }^{13} \mathrm{C}$ chemical shift axis)

c. $\mathrm{V}_{1}=\mathrm{V}_{\mathrm{CH}}\left(\right.$ on ${ }^{1} \mathrm{H}$ and ${ }^{13} \mathrm{C}$ chemical shift axes)

3. Cluster the undirected graph G. Matrix A is $\mathrm{G}_{\mathrm{ij}}$. The node set containing all combinations of ${ }^{1} \mathrm{H}$ and ${ }^{13} \mathrm{C}$ chemical shifts in the undirected graphs $\mathrm{G}_{\mathrm{i}}$ and $\mathrm{G}_{\mathrm{j}}$ is $\mathrm{V}_{\mathrm{ij}} ; i$ and $j$ are the number of graphs, $\mathrm{G}$, which contain 3 peaks, and the length is the same. If node sets $\mathrm{V}_{\mathrm{i}}$ and $\mathrm{V}_{\mathrm{j}}$ have the node of the same chemical shift and the node is a HSQC peak, chain assignment of the peaks in the two graphs, G, is possible.

$G_{i j}=\left\{\begin{array}{l}1, v_{3 i}=v_{1 j}^{\prime} \\ 0, \text { otherwise }\end{array}\right.$

4. Construct the undirected graph $\mathrm{G}_{\mathrm{HH}}$ of $\mathrm{HSQC}$ on the ${ }^{1} \mathrm{H}$ chemical shift axis, as was not the case for the previous conditions. The node set is $\mathrm{V}_{\mathrm{HH}}$ $=\left\{\mathrm{HH}_{1}, \mathrm{HH}_{2}\right\}$ and the node set of ${ }^{13} \mathrm{C} \mathrm{COSY}$ or ${ }^{13} \mathrm{C}$ TOCSY is $\mathrm{Vc}=\left\{\mathrm{Cl}_{1}, \mathrm{C}_{2}\right\}$. Here, when two HSQC signals have the same ${ }^{1} \mathrm{H}$ chemical shift, these signals are connected.

a. $\mathrm{HH}_{1}={ }_{\mathrm{HH} 2}\left(\right.$ on ${ }^{1} \mathrm{H}$ chemical shift axis)

b. $\mathrm{HH}_{1}=\mathrm{c}_{1}$ and $\mathrm{HH}_{2}=\mathrm{c}_{2}$ (on ${ }^{13} \mathrm{C}$ chemical shift axis)

5. Construct the undirected graph $\mathrm{G}_{\mathrm{CC}}$ of HSQC on the ${ }^{13} \mathrm{C}$ chemical shift axis, as was not the case for the previous conditions. The node set is Vcc $=\left\{\mathrm{cc}_{1}, \mathrm{cc}_{2}\right\}$ and the node set of ${ }^{1} \mathrm{H}$ COSY or ${ }^{1} \mathrm{H}$ TOCSY is $\mathrm{V}_{\mathrm{H}}=\left\{\mathrm{H}_{1}, \mathrm{H} 2\right\}$. Here, when two HSQC signals have the same ${ }^{13} \mathrm{C}$ chemical shift, these signals are connected.

a. $\mathrm{cc}_{1}=\mathrm{cc}_{2}$ (on ${ }^{13} \mathrm{C}$ chemical shift axis)

b. $\mathrm{cc}_{1}={ }_{\mathrm{H} 1}$ and $\mathrm{CC} 2={ }_{\mathrm{H} 2}$ (on ${ }^{1} \mathrm{H}$ chemical shift axis)

6. Extract the HSQC signal as a single component $\mathrm{x}$, as was not the case for the previous conditions.

7. Determine the connection with quaternary carbon. $y$ is all of the components contained in $A, \mathrm{G}_{\mathrm{HH}}, \mathrm{G}_{\mathrm{CC}}$, and $\mathrm{x}$. The component of ${ }^{13} \mathrm{C}$ COSY and/or ${ }^{13} \mathrm{C}$ TOCSY is $\mathrm{z}$, as was not the case for the previous conditions. The estimated connection matrix B with $\mathrm{y}$ and $\mathrm{z}$ is $\mathrm{X}_{\mathrm{ij} \text {. }}$ 
$\mathrm{X}_{\mathrm{ij}}=\left\{\begin{array}{l}1, \mathrm{y}_{\mathrm{i}}=\mathrm{z}_{\mathrm{j}}\left(\text { on }{ }^{13} \mathrm{C} \text { chemical shift axis) }\right. \\ 0, \text { otherwise }\end{array}\right.$

The analytical flow is shown in Figure 2, and the details of these algorithm steps are visualized in Figure S7.

\section{Database Searching}

SpinAssign $^{10}$ and $\mathrm{BMRB}^{I 1}$ were used to search for components. $\mathrm{HMDB}^{I 2}$ was used to obtain the chemical shifts of the fragment structures. Candidate components for which all HSQC signals were detected were listed. All correlation signals were calculated and peaks were annotated

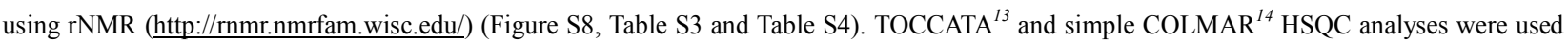
for comparison with the method developed in this study (Figure S4, Table S3).

\section{Structure Estimation Based on Graph Isomorphism Theory}

Each ${ }^{1} \mathrm{H}-{ }^{13} \mathrm{C}$ HSQC peak was searched against the database. Next, we performed cluster analysis using the Levenshtein distance ${ }^{15}$ of the Hierarchical Organization of Spherical Environments (HOSE) $\operatorname{code}^{16}$ of the partial structure written using NMRshiftDB2 (http://nmrshiftdb.nmr.uni-koeln.de/) to extract matching compounds. Almost all compounds matched by database searching using ${ }^{1} \mathrm{H}-{ }^{13} \mathrm{C}$ HSQC peaks had the same partial structures. To extract matched compounds with similar partial structures, the structures of the ${ }^{1} \mathrm{H}-{ }^{13} \mathrm{C}$ HSQC peaks were predicted by the most common substructure (MCS) algorithm ${ }^{17}$ using the Chemistry Development Kit (CDK) library ${ }^{18}$ written by Java language. The full structure was predicted to connect the partial structures based on the bonding ranking of COSY.

\section{Conformational Analysis and Calculation of Theoretical Chemical Shifts}

The experimental chemical shift was compared with the theoretical value for validation of a predicted structure. First, a chemical conformation was created with Winmostar (http://winmostar.com/jp/). Next, to generate a plurality of structures by grid searching after molecular minimization by VEGA ZZ (http://nova.disfarm.unimi.it/), all structures were extracted as a coordinate by a CatDCD function (http://www.ks.uiuc.edu/Development/MDTools/). The total energy was calculated after molecular optimization by the PM7 method using MOPAC2012 (http://openmopac.net/). Furthermore, 10 coordinates of the energetically stable structure in all coordinates were extracted after the removal of similar coordinates by the dihedral angle difference root mean square (RMS) comparison method (1) on an R platform as follows:

$$
d=\sqrt{\left(\sum_{i=1}^{M}\left(X_{i}-Y_{i}\right)^{2}\right) / M}
$$

where $\mathrm{X}$ and $\mathrm{Y}$ are dihedral angles of the $\mathrm{i}^{\text {th }}$ dihedral angle in the same position in different conformations, and $\mathrm{M}$ is the total number of dihedral angles.

The dihedral angle is calculated by equation (2) as follows:

$$
\cos \theta=\frac{\mathrm{N}_{\mathrm{a}} \cdot \mathrm{N}_{\mathrm{b}}}{\left|\mathrm{N}_{\mathrm{a}}\right|\left|\mathrm{N}_{\mathrm{b}}\right|} \quad\left[\theta=0-180^{\circ}\right]
$$


The normal vector $\mathrm{N}_{\mathrm{a}}$ of the plane $\mathrm{ABC}$ and the normal vector $\mathrm{N}_{\mathrm{b}}$ of the plane $\mathrm{BCD}$ are determined from the cross product of the vectors as follows:

$$
\begin{aligned}
& \mathrm{N}_{\mathrm{a}}=\overrightarrow{\mathrm{BA}} \times \overrightarrow{\mathrm{BC}} \\
& \mathrm{N}_{\mathrm{b}}=\overrightarrow{\mathrm{CB}} \times \overrightarrow{\mathrm{CD}}
\end{aligned}
$$

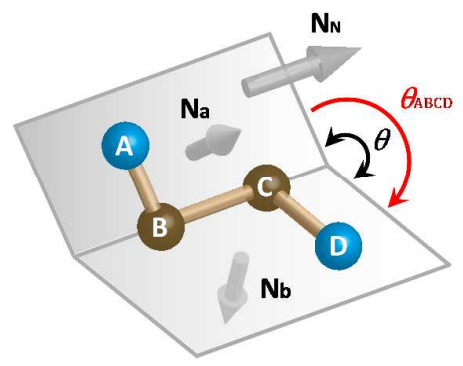

The connection of $\mathrm{ABCD}$ indicates the arrangement of atoms in a compound, for example, $\mathrm{H}-\mathrm{C}-\mathrm{C}-\mathrm{H}$. The direction of the dihedral angle is determined by equations (5) and (6), and the dihedral angle with direction is given by equation (7) as follows:

$$
\begin{aligned}
& N_{N}=N_{a} \times N_{b} \\
& \text { Coef. }=\frac{\overrightarrow{B C} \cdot N_{N}}{|\overrightarrow{B C}|\left|N_{N}\right|} \quad[\text { Coef. }=-1 \text { or } 1] \\
& \theta_{\text {ABCD }}=\theta \cdot \text { Coef. } \quad\left[\theta_{\mathrm{ABCD}}=-180 \text { to } 180^{\circ}\right]
\end{aligned}
$$

Molecular optimization and theoretical chemical shifts were calculated quantum-chemically with the Gaussian09 program (http://www.gaussian.com/) installed in the RIKEN Integrated Cluster of Clusters (RICC). The calculations were performed at the B3LYP/6-311++G(d,p)//GIAO/B3LYP/6-311++G(d,p) level ${ }^{19-21}$ with the polarizable continuum model (PCM) $)^{22}$ method. The PCM method was used to consider solvent effects on the solute. All structures in this study were calculated by the PCM method using a water model. In addition, the case of adding water molecules around the solute was calculated. The results from both these calculations were similar (Table S7); however, the calculation with added water molecules required much more calculation time. Therefore, the PCM method, which includes water effects without adding water molecules, was used in this study. The combination of B3LYP as a density functional theory (DFT) and Pople basis set is used widely for the calculation of theoretical NMR chemical shifts, as this calculation level can provide highly reliable results. ${ }^{23,}{ }^{24}$ In addition, for the B3LYP/6-311++G(d,p) level, the calculations were completed in short times by parallel calculation. DSS was calculated as a reference material at the same level. The theoretical chemical shift of the ionized structure of the most stable structure was also calculated for comparison with the non-ionized structure. Theoretical chemical shifts calculated using only the most stable structure do not necessarily coincide with the experimental values. Accordingly, in this study, two correction methods using several stable structures were applied with the aim of lending support to the estimated shifts. A weighted average of the existence probability $\left(\mathrm{p}_{\mathrm{i}}\right)$ based on the Boltzmann distribution ${ }^{25}(8)$ and regression analysis or multiple regression analysis ${ }^{26}$ were calculated for correction of the theoretical chemical shifts. Regression analysis is mostly used for correcting theoretical 
chemical shifts, and a linear scaling factor is used for the calculation level. The energy level is different in each Hamiltonian that is used in the Boltzmann distribution correction. Therefore, multiple regression analysis of the chemical shifts was used to calculate the contribution factor to each conformation.

$$
\mathrm{p}_{\mathrm{i}}=\frac{e^{-\delta \mathrm{E}_{\mathrm{i}} /(\mathrm{RT})}}{\sum_{\mathrm{i}} e^{-\delta \mathrm{E}_{\mathrm{i}} /(\mathrm{RT})}} \cdot 100
$$

where $\mathrm{R}$ is the ideal gas constant, $\mathrm{T}$ is the absolute temperature, and $\delta \mathrm{Ei}$ is the standard free energy value of the $\mathrm{i}^{\text {th }}$ conformer relative to the energy of the most stable conformer. The corrected chemical shift is calculated by equation (9) as follows:

$$
\delta^{1} \mathrm{H}_{\text {calc. }}=\frac{\sum_{\mathrm{i}=1}^{\mathrm{n}}\left(\mathrm{p}_{\mathrm{i}} \delta^{1} \mathrm{H}_{\text {Theo. }}\right)}{100}
$$

Equation (10) is a general regression model for the corrected chemical shift:

$$
\delta^{1} \mathrm{H}_{\text {calc. }}=\mathrm{x}+\mathrm{y} \delta^{1} \mathrm{H}_{\text {Theo }}
$$

where $\mathrm{x}$ is the overall correction value of error between the experimental and theoretical chemical shift, and $\mathrm{y}$ is the correction factor for the slope between the experimental and theoretical chemical shift.

Equation (11) is a general multiple regression model for the corrected chemical shift:

$$
\delta^{1} \mathrm{H}_{\text {calc. }}=\mathrm{x}+\sum_{\mathrm{i}=1}^{\mathrm{n}}\left(\mathrm{y}_{\mathrm{i}} \delta^{1} \mathrm{H}_{\text {Theo. } \mathrm{i}}\right)
$$

where $\mathrm{x}$ is the overall correction value of error between the experimental and theoretical chemical shift, and $\mathrm{y}_{\mathrm{i}}$ is the importance value for the $\mathrm{i}^{\text {th }}$ conformer. To determine the permissible range of error between the calculated and experimental chemical shifts, the confidence and prediction intervals were calculated. If the calculated chemical shifts of ${ }^{1} \mathrm{H}$ and ${ }^{13} \mathrm{C}$ were within the prediction interval, the estimated structure was considered to be reasonable. ${ }^{27}$

\section{Refining Estimated Compounds by Solubility in Water}

We needed to determine whether the estimated compounds could be detected experimentally by NMR in any of the solvents used because it is also possible to perform chemical shift calculations for compound that are insoluble in water. Therefore, a final refinement method for the estimated structures was implemented. A search of the solubility of the compounds in water was conducted using the chemistry databases PubChem (https://pubchem.ncbi.nlm.nih.gov/), HMDB, and Santa Cruz Biotechnology (http://www.scbt.com/index.html). If the solubility was extremely low, the estimated structure was considered not suitable (Table S6). In general, when the estimated structure is an unknown compound, the solubility can be estimated and evaluated using COSMO-RS (http://www.cosmologic.de/products/cosmotherm.html) and ALOGPS (http://www.vcclab.org/lab/alogps/). The aqueous solubility of 18 compounds was also evaluated by using ALOGPS 2.1, which was calculated by artificial neural networks aqueous solubility for a diverse set of 1291 organic compounds. ${ }^{28}$ 


\section{Supplementary Results and Discussion}

\section{Usefulness of NUS}

For biological extracts, a highly concentrated sample and/or long NMR experimental time are necessary. The NUS method was very effective for shortening the experimental time when using a plurality of pulse programs, as demonstrated in this study. The total NMR experimental time was shortened by between a half and a quarter compared with the traditional method. This study showed that the NUS method and ${ }^{13} \mathrm{C}$ labeling technique enabled the comprehensive detection of compounds with high sensitivity and a short experimental time.

\section{Evaluation of Chemical Shifts by Quantum Chemical Calculation}

The possibility of theoretical assignment performed by quantum chemical calculation using predicted structures was suggested by the comparison of experimental and theoretical chemical shifts. To date, theoretical NMR calculation and correction methods that markedly match experimental chemical shifts have not been established. In this study, the validity of the structures was evaluated comprehensively using four commonly used methods. The theoretical chemical shifts of ionized structures tended to show large errors compared with the experimental chemical shifts. Correction by weighting using presence probability was considered to reflect the sample state, and the results showed some improvement compared with the calculation using the most stable structure. In addition, the calculation level may have certain errors, so linear scaling correction by regression analysis was useful. The theoretical chemical shifts of wrongly assembled chemical fragments or wrong conformations that exhibited large errors compared with the experimental values were considered. From this, the correct assembly and conformation of chemical fragments could be selected. Furthermore, evaluation of the validity of the precise structure was expected by using a high calculation level, such as $\operatorname{CCSD}(\mathrm{T}) .{ }^{29}$ The quantum chemical calculations were finished within $3 \mathrm{~h}$ with parallel calculations using 32 core computations per compound. 

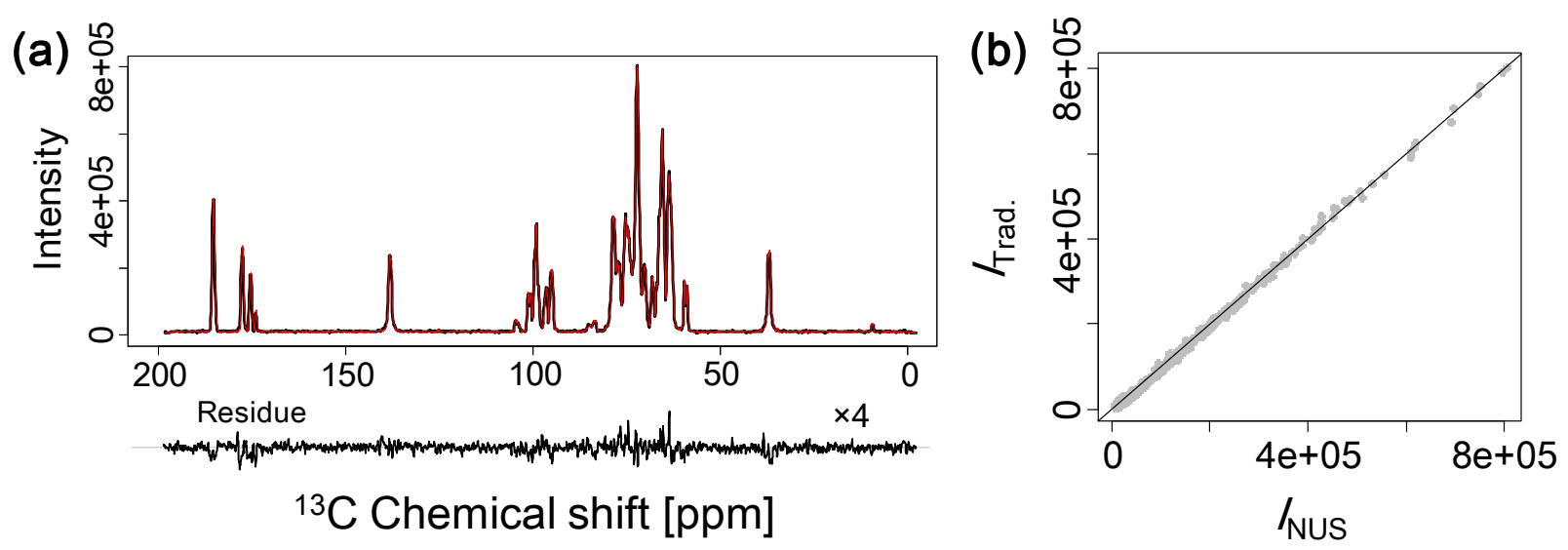

Supplementary Figure S1. The intensity of the NUS ${ }^{13} \mathrm{C}-{ }^{13} \mathrm{C}$ COSY spectrum is compared with a conventional spectrum measured using a standard mixture. (a) Projection data of the NUS spectrum (red) overlaps with the conventional spectrum (black). (b) The trend line is fitted with equation $I_{\text {Trad. }}=0.9999 I_{\mathrm{NUS}}-0.203$ with $\mathrm{R}^{2}=0.9986$. 
(a)

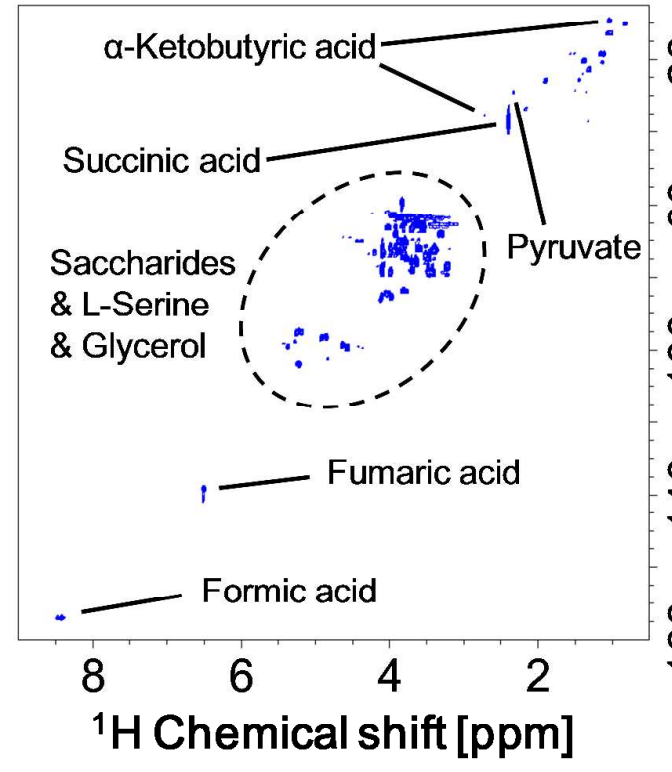

(b)

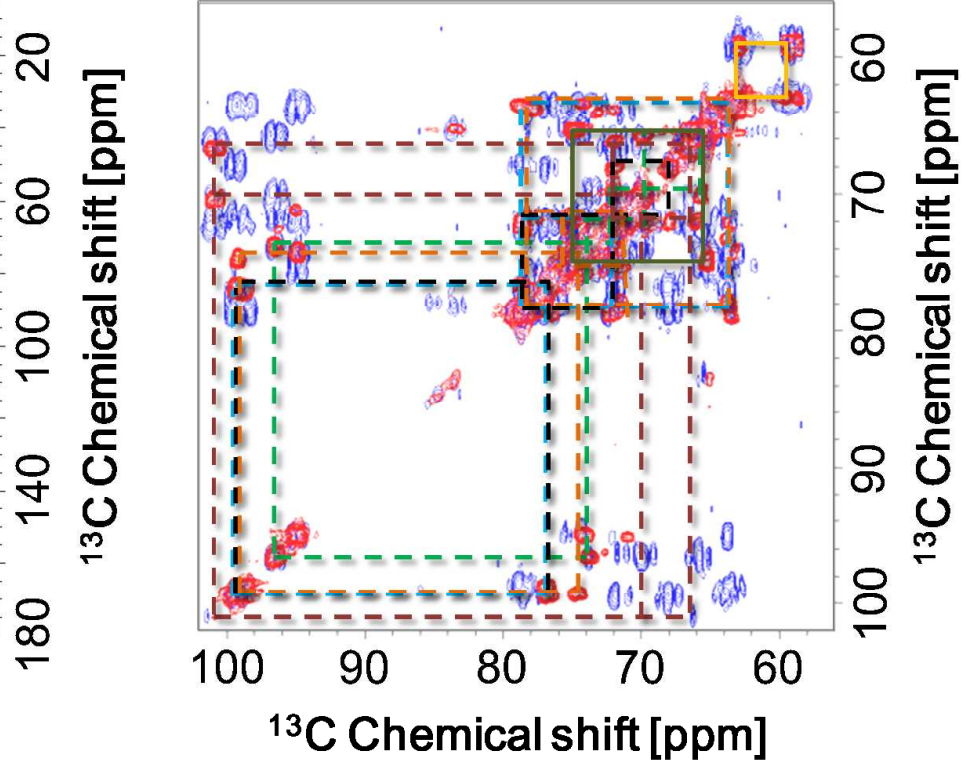

(c)
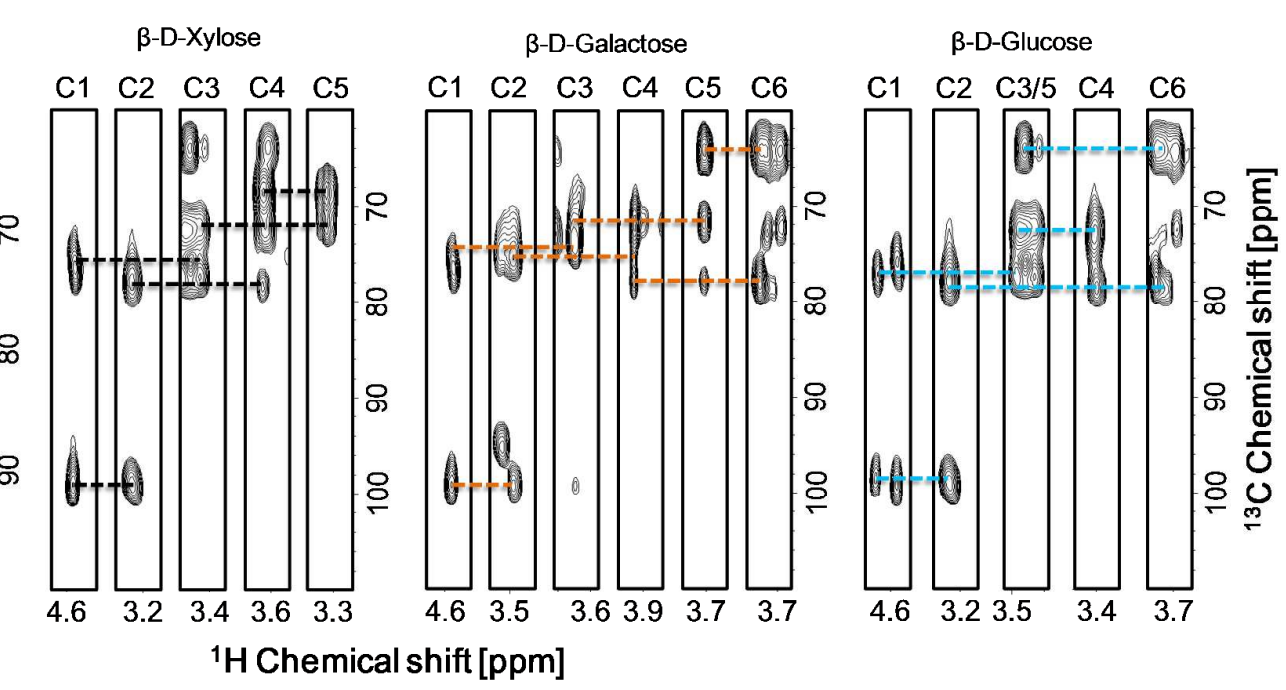

$\begin{array}{llllll}4.9 & 3.5 & 4.0 & 3.9 & 3.8\end{array}$

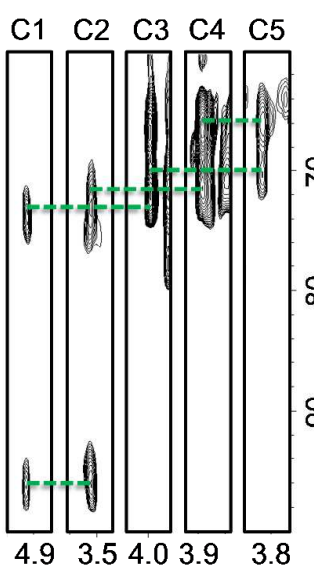

${ }^{1} \mathrm{H}$ Chemical shift [ppm]

Supplementary Figure S2. Multidimensional NMR spectra of the standard mixture. (a) Full region of ${ }^{1} \mathrm{H}-{ }^{13} \mathrm{C}$ HSQC spectrum. (b) Saccharide area of ${ }^{13} \mathrm{C}-{ }^{13} \mathrm{C}$ COSY (red) and ${ }^{13} \mathrm{C}-{ }^{13} \mathrm{C}$ TOCSY (blue) with chain assignment by the manual method (- - -: $\beta$-D-fructose, - - -: $\beta$-D-galactose, - - -: $\beta$-D-glucose, - - -: $\beta$-D-ribose, - - -: $\beta$-D-xylose, -: glycerol, and -: L-serine). (c) The networks of D-ribose, D-xylose, D-galactose, and D-glucose are confirmed by strip plots of the HCCH-COSY spectrum. 


\section{Fumaric acid}

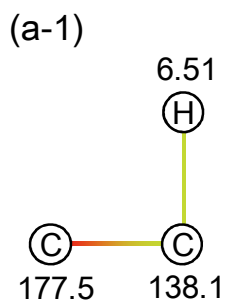

(b-1)

(a-2)

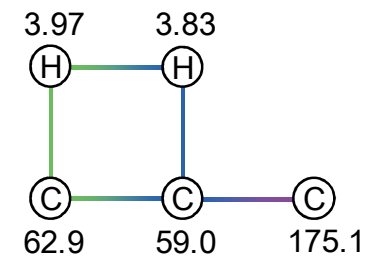

L-Serine

(c-1)
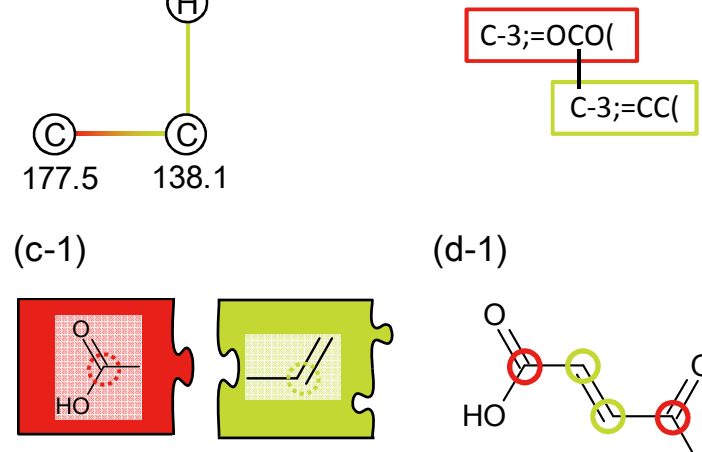

(d-1)

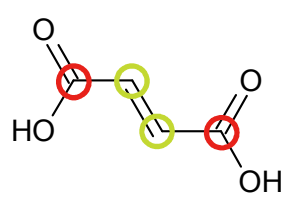

(c-2)

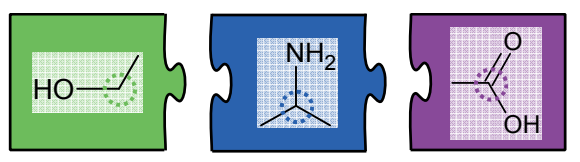

(d-2)

(b-2)

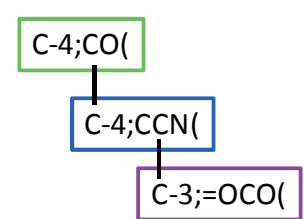

$\beta-D-R i b o s e$

(a-3)

3.83

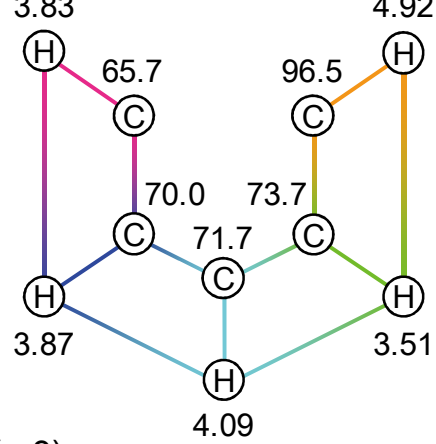

(c-3)
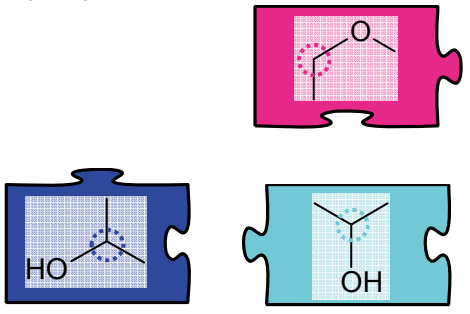

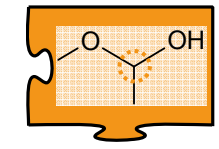

(b-3)

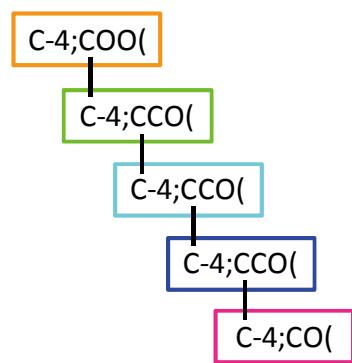

(d-3)
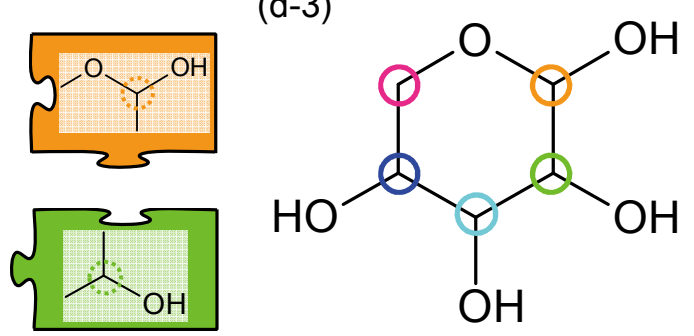

Supplementary Figure S3. Fragment assembly approach using the correlation signals of components in the standard mixture. (a) A backbone chemical structure determined by automatic network analysis (Figure 1b). The numbers are ${ }^{1} \mathrm{H}$ and ${ }^{13} \mathrm{C}$ chemical shifts [ppm]. (b) HOSE code of the expected partial structure from the database search, and cluster analysis and MCS analysis of the metabolites obtained by the database search. The binding of adjacent carbon is shown. (c) Each estimated partial structure. The circle indicates the $\mathrm{C}-\mathrm{H}$ corresponding to the chemical shift. (d) The entire structure is constructed using the backbone information and each partial structure. Fumaric acid, L-serine, and $\beta$-D-ribose are shown as examples. The circle indicates the $\mathrm{C}-\mathrm{H}$ corresponding to the chemical shift. 


\section{${ }^{13} \mathrm{C}-{ }^{1} \mathrm{H}$ HSQC Query}

Select an area to zoom in. Click on top-right to save figure. Click on blue point to show
matched compound(s)

0

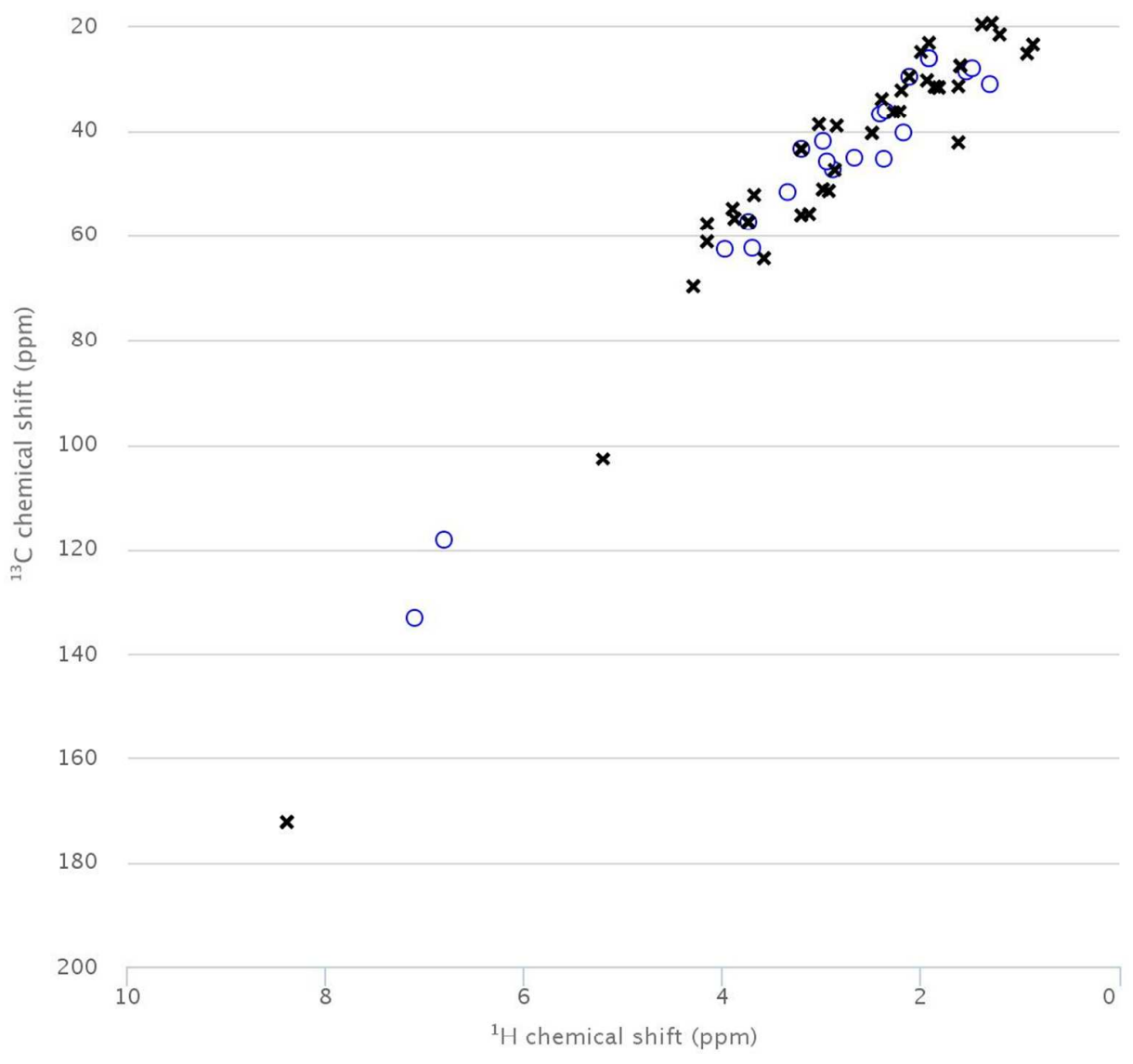

Click to hide/show

- your data that match multiple compounds

$\bigcirc$ your data that match single compound

$x$ your data that don't match any compound

Supplementary Figure S4. COLMAR analysis using HSQC signals in C. brachypus. The analysis was used for comparison with the method developed in this study. The chemical shifts and possibility of annotation are shown in Table S3. 
(a)

(b)
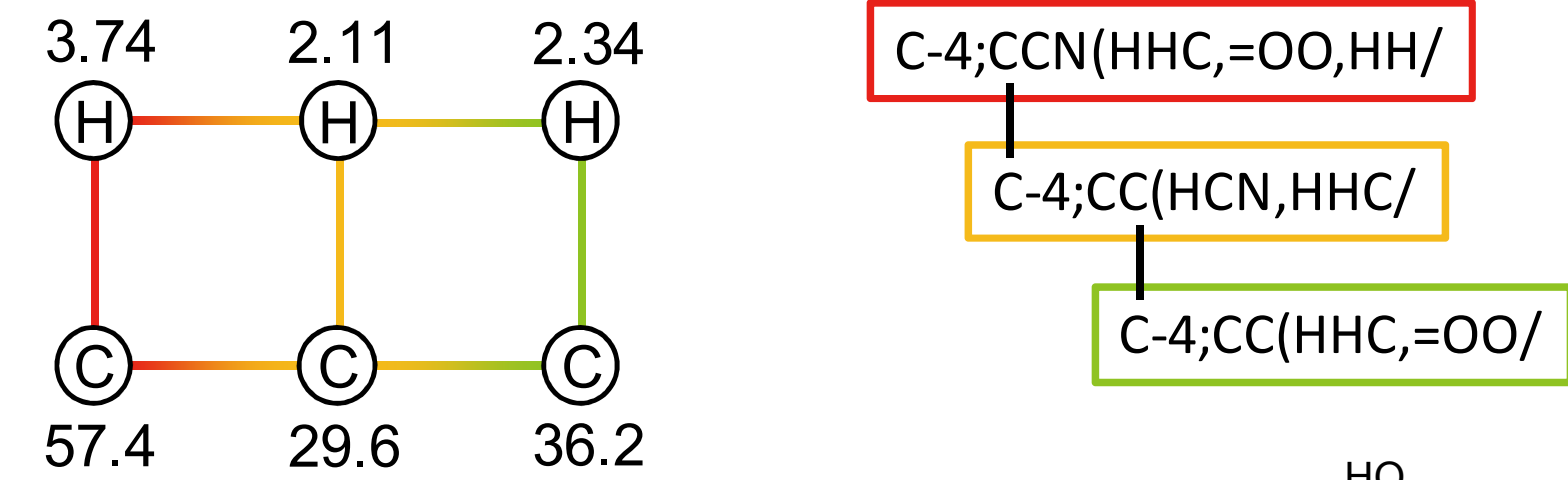

(c)
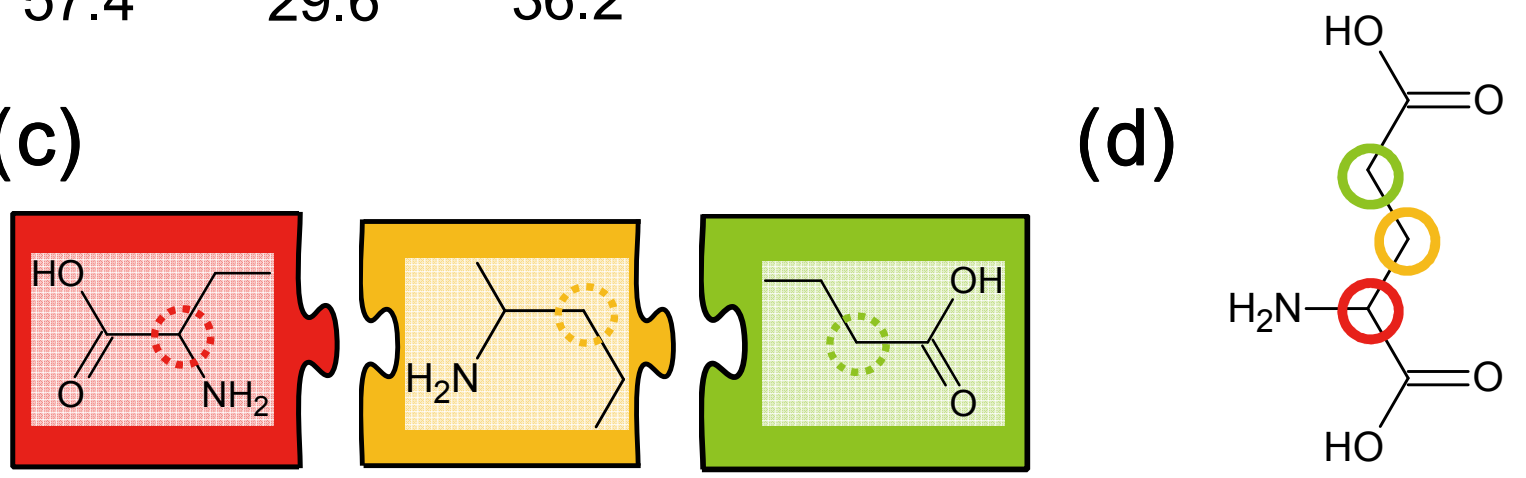

Supplementary Figure S5. Fragment assembly approach using the correlation signals of L-glutamate in C. brachypus. (a) A backbone chemical structure determined by automatic network analysis (Figure 3a). The numbers are the ${ }^{1} \mathrm{H}$ and ${ }^{13} \mathrm{C}$ chemical shifts [ppm]. (b) HOSE code of the expected partial structure from the database search, and cluster analysis and MCS analysis of the metabolites obtained by the database search. The binding of adjacent carbon is shown. (c) Each estimated partial structure. The circle indicates the $\mathrm{C}-\mathrm{H}$ corresponding to the chemical shift. (d) The entire structure is constructed using the backbone information and each partial structure. The circle indicates the $\mathrm{C}-\mathrm{H}$ corresponding to the chemical shift. 

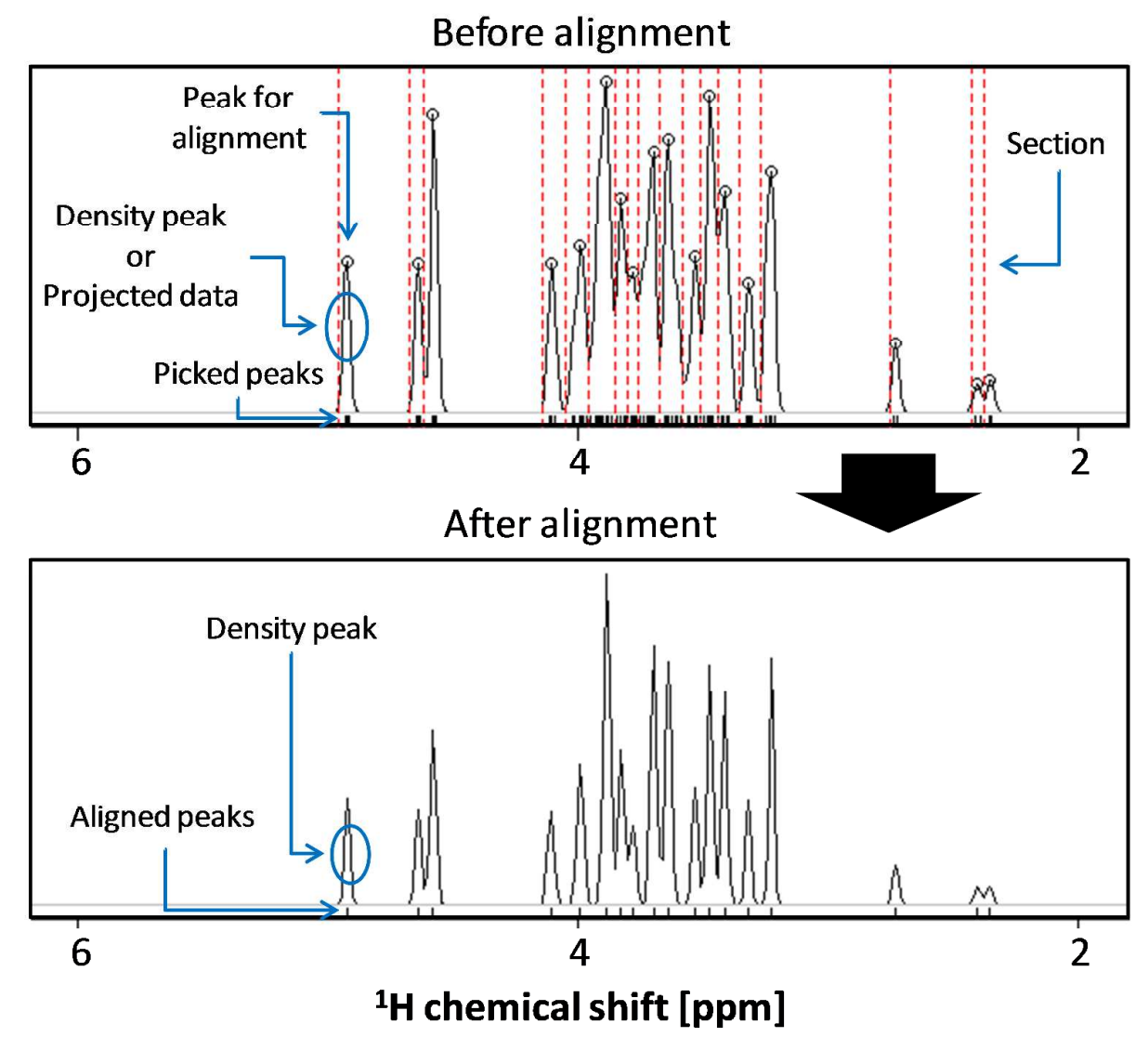

Supplementary Figure S6. Alignment of NMR signals in the mixture of 12 standards for automatic chain assignment. Shown is the case for the ${ }^{1} \mathrm{H}$ chemical shifts with the peaks obtained from the HSQC $\left(\mathrm{F} 2 ;{ }^{1} \mathrm{H}\right)$ and HSQC-TOCSY $\left(\mathrm{F} 2 ;{ }^{1} \mathrm{H}\right)$ spectra. Bandwidth: 0.01, point size: 1024 , range: 0-10 ppm; these parameters were set as an example. The sections are detected by the density peaks or projected data, and the picked peaks are aligned by section. 


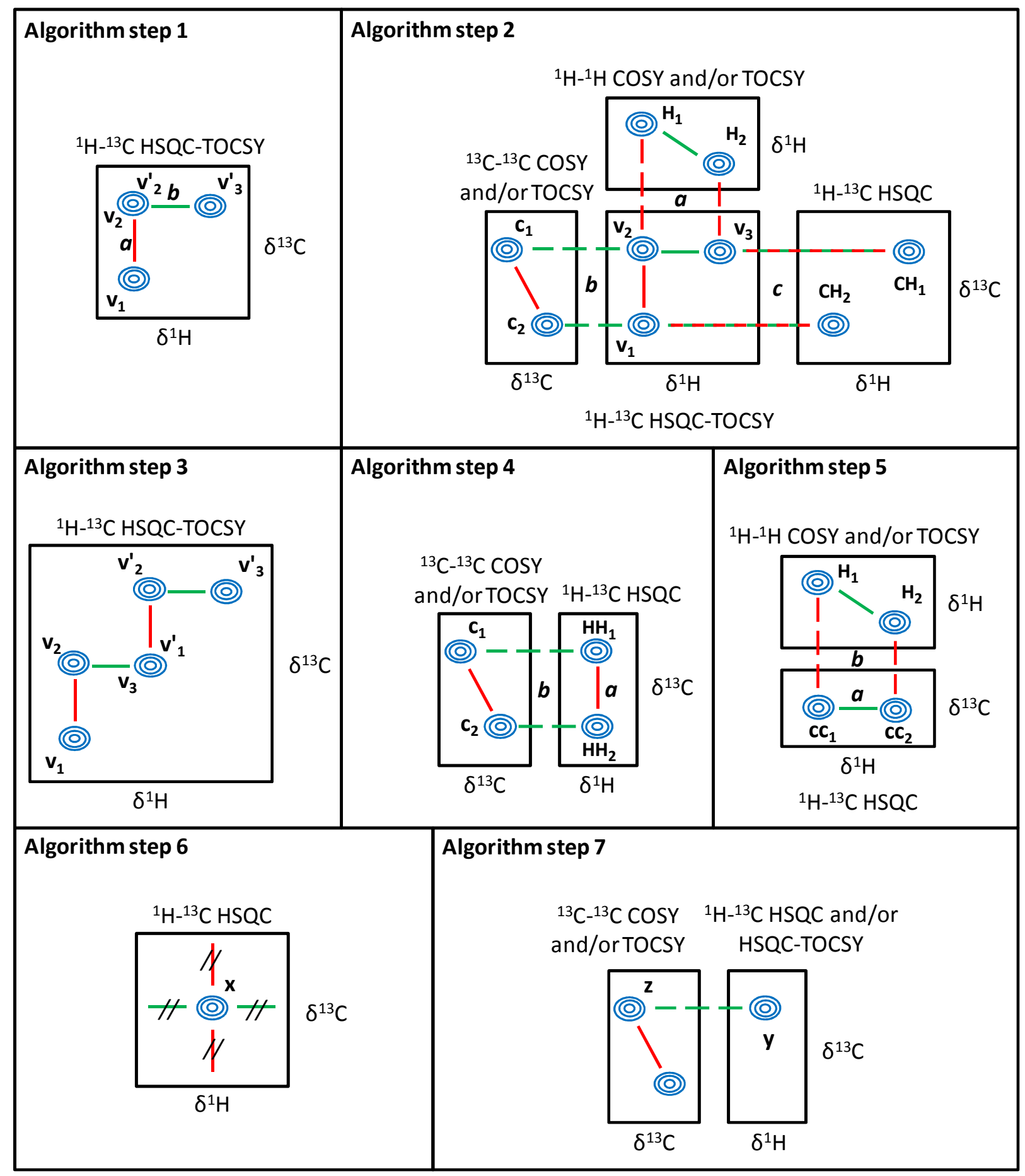

Supplementary Figure S7. Each processing step of the automatic chain assignment algorithm. A detailed description is given in the Supplementary Methods. 

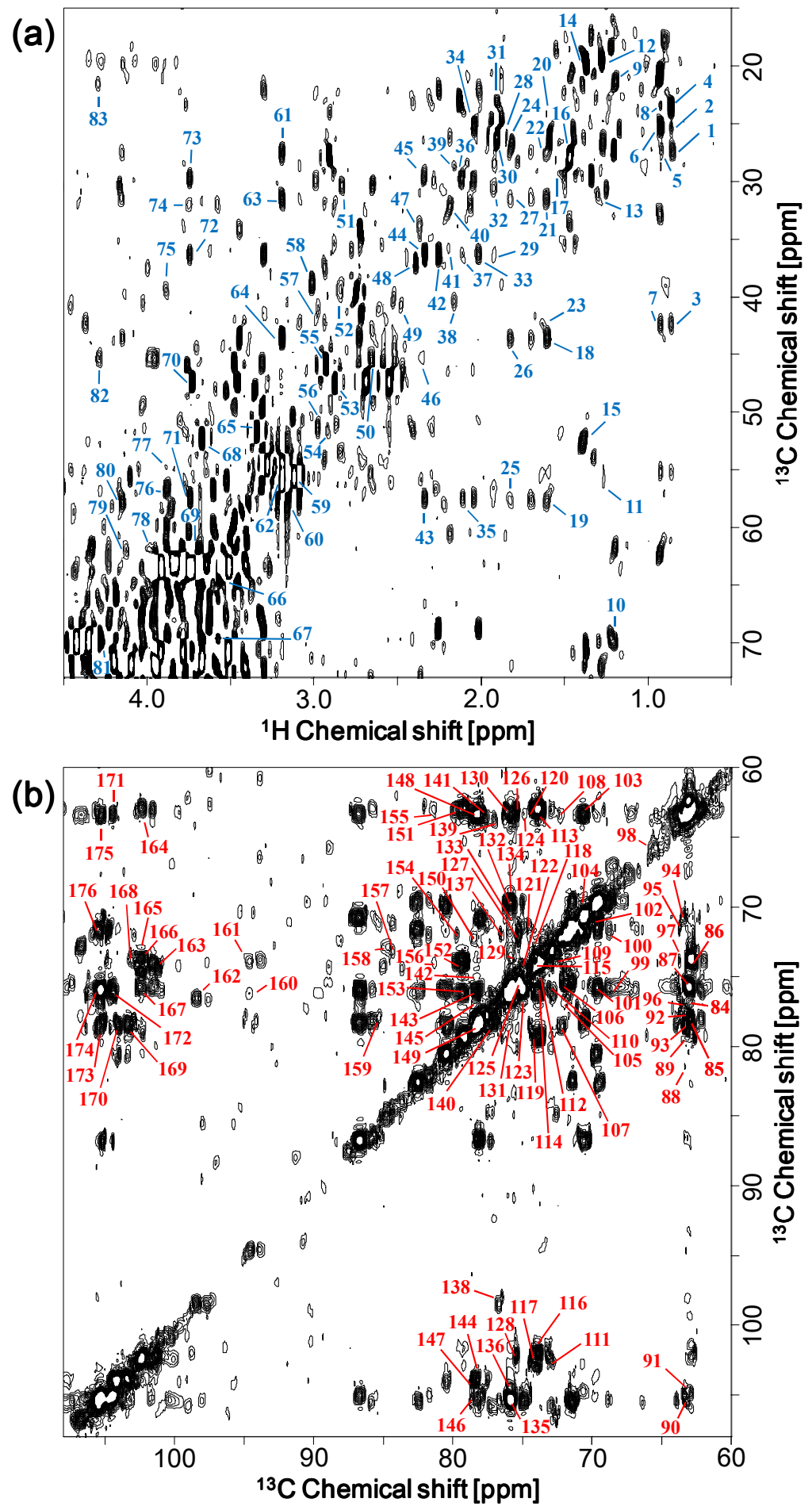

Supplementary Figure S8. Multidimensional NMR spectra of C. brachypus. (a) The region of high magnetic field in the ${ }^{1} \mathrm{H}-{ }^{13} \mathrm{C}$ HSQC-TOCSY spectrum. (b) The saccharide area of the ${ }^{13} \mathrm{C}-{ }^{13} \mathrm{C}$ TOCSY spectrum. The numbers in the spectra correspond to the annotation of components in Table S3 and Table S4. 
Supplementary Table S1. Pulse sequences, parameters, and conditions of NMR measurements.

\begin{tabular}{|c|c|c|c|c|c|c|c|c|c|c|c|c|c|c|}
\hline Sample & Experiment & Pulse program & $\begin{array}{c}\text { Magnetic } \\
\text { field }\end{array}$ & Probe & NUS [\%] & $\begin{array}{c}\text { NUS } \\
\text { process }\end{array}$ & NS & $\mathrm{TD}(\mathrm{F} 3)$ & $\mathrm{TD}(\mathrm{F} 2)$ & $\mathrm{TD}(\mathrm{F} 1)$ & $\begin{array}{c}\text { Mixing } \\
\text { time }[\mathrm{ms}]\end{array}$ & $J_{\mathrm{CH}}[\mathrm{Hz}]$ & $\mathrm{D} 1[\mathrm{~s}]$ & Exp. time $[\mathrm{h}]$ \\
\hline Std. Mix. & ${ }^{1} \mathrm{H}-{ }^{13} \mathrm{C}$ HSQC & hsqcetgpsp.3 & $600 \mathrm{MHz}$ & TCI & 50 & CS & 32 & - & 2048 & 512 & - & 140 & 1.5 & 3.4 \\
\hline Std. Mix. & ${ }^{1} \mathrm{H}-{ }^{13} \mathrm{C}$ HSQC-TOCSY & hsqcdietgpsisp & $600 \mathrm{MHz}$ & $\mathrm{TCI}$ & 50 & CS & 32 & - & 2048 & 512 & 60 & 145 & 1.5 & 3.4 \\
\hline Std. Mix. & ${ }^{1} \mathrm{H}-{ }^{13} \mathrm{C}$ CT-HSQC & hsqcctetgpsp & $700 \mathrm{MHz}$ & TCI & - & - & 12 & - & 2048 & 1600 & - & 145 & 1.0 & 5.3 \\
\hline Std. Mix. & ${ }^{1} \mathrm{H}-{ }^{13} \mathrm{C} C \mathrm{C}-\mathrm{HSQC}-\mathrm{TOCSY}$ & hsqcctetgpsisp ** & $700 \mathrm{MHz}$ & TCI & - & - & 24 & - & 2048 & 1600 & 50 & 145 & 1.0 & 10.7 \\
\hline Std. Mix. & ${ }^{13} \mathrm{C}-{ }^{13} \mathrm{C} \cos \mathrm{Y}^{*}$ & cosygpppqf $* *$ & $500 \mathrm{MHz}$ & $\mathrm{DCH}$ & - & - & 4 & - & 2048 & 512 & - & - & 3.0 & 1.7 \\
\hline Std. Mix. & ${ }^{13} \mathrm{C}-{ }^{13} \mathrm{C} \cos \mathrm{Y}$ & cosygpppqf $* *$ & $500 \mathrm{MHz}$ & $\mathrm{DCH}$ & 25 & CS & 16 & - & 2048 & 512 & - & - & 3.0 & 1.7 \\
\hline Std. Mix. & ${ }^{13} \mathrm{C}-{ }^{13} \mathrm{C}$ TOCSY & c_ccflopsy16 ** & $500 \mathrm{MHz}$ & $\mathrm{DCH}$ & 25 & CS & 256 & - & 1024 & 384 & 40 & - & 4.0 & 27.3 \\
\hline Std. Mix. & ${ }^{13} \mathrm{C}-{ }^{13} \mathrm{C}$ CT-COSY & c_cosy2_ct $* *$ & $600 \mathrm{MHz}$ & $\mathrm{DCH}$ & 30 & CS & 32 & - & 4096 & 1400 & - & - & 3.0 & 11.2 \\
\hline Std. Mix. & ${ }^{13} \mathrm{C}-{ }^{13} \mathrm{C}$ CT-TOCSY & c_ccflopsy16_ct $* *$ & $600 \mathrm{MHz}$ & $\mathrm{DCH}$ & 30 & CS & 32 & - & 4096 & 1400 & 47 & - & 3.0 & 11.2 \\
\hline Std. Mix. & $\mathrm{HCCH}-\mathrm{COSY}$ & hcchoogp3d2 & $600 \mathrm{MHz}$ & TCI & 25 & CS & 16 & 1024 & 128 & 64 & - & 140 & 1.0 & 9.1 \\
\hline C. brachypus & ${ }^{1} \mathrm{H}-{ }^{13} \mathrm{C}$ HSQC & hsqcetgpsp. 3 & $600 \mathrm{MHz}$ & $\mathrm{TCI}$ & 50 & CS & 16 & - & 2048 & 1024 & - & 140 & 1.5 & 3.4 \\
\hline C. brachypus & ${ }^{1} \mathrm{H}-{ }^{13} \mathrm{C}$ HSQC & hsqcetgpsi2 & $700 \mathrm{MHz}$ & TCI & - & - & 48 & - & 1024 & 256 & - & 145 & 1.0 & 3.4 \\
\hline C. brachypus & ${ }^{1} \mathrm{H}-{ }^{13} \mathrm{C}$ HSQC-TOCSY & hsqcdietgpsisp & $600 \mathrm{MHz}$ & TCI & 50 & CS & 16 & - & 2048 & 1024 & 60 & 145 & 1.5 & 3.4 \\
\hline C. brachypus & ${ }^{1} \mathrm{H}-{ }^{13} \mathrm{C}$ HSQC-TOCSY & hsqcdietgpsisp & $700 \mathrm{MHz}$ & TCI & - & - & 48 & - & 1024 & 256 & 60 & 145 & 1.0 & 3.4 \\
\hline C. brachypus & ${ }^{1} \mathrm{H}-{ }^{13} \mathrm{C}$ CT-HSQC & hsqcctetgpsp & $700 \mathrm{MHz}$ & TCI & 25 & CS & 192 & - & 4096 & 1300 & - & 145 & 1.0 & 17.3 \\
\hline C. brachypus & ${ }^{1} \mathrm{H}-{ }^{13} \mathrm{C}$ CT-HSQC-TOCSY & hsqcctetgpsisp ** & $700 \mathrm{MHz}$ & TCI & 25 & CS & 336 & - & 2048 & 1600 & 50 & 145 & 1.0 & 37.3 \\
\hline C. brachypus & ${ }^{1} \mathrm{H}-{ }^{1} \mathrm{H}$ TOCSY $*$ & mlevphpr & $700 \mathrm{MHz}$ & $\mathrm{TCI}$ & - & - & 16 & - & 2048 & 256 & 60 & - & 2.0 & 2.3 \\
\hline C. brachypus & ${ }^{13} \mathrm{C}-{ }^{13} \mathrm{C}$ TOCSY & c_ccflopsy16 $* *$ & $500 \mathrm{MHz}$ & $\mathrm{DCH}$ & 25 & CS & 192 & - & 1024 & 384 & 40 & - & 3.0 & 15.4 \\
\hline C. brachypus & ${ }^{13} \mathrm{C}-{ }^{13} \mathrm{C}$ CT-CosY $*$ & c_cosy2_ct $* *$ & $600 \mathrm{MHz}$ & $\mathrm{DCH}$ & 25 & CS & 496 & - & 8192 & 400 & - & - & 3.0 & 41.3 \\
\hline C. brachypus & HCCH-COSY & hcchoogp3d2 & $600 \mathrm{MHz}$ & TCI & 25 & $\mathrm{CS}$ & 16 & 1024 & 128 & 64 & - & 140 & 1.0 & 9.1 \\
\hline
\end{tabular}

* These measurements were not eventually used for the assignment of components. Traditional ${ }^{13} \mathrm{C}-{ }^{13} \mathrm{C}$ COSY of the standard mixture was only measured for comparison with the applied NUS data. The

${ }^{1} \mathrm{H}-{ }^{1} \mathrm{H}$ TOCSY signals were hardly observed in C. brachypus; therefore, the $\mathrm{H}-\mathrm{H}$ correlation data from ${ }^{1} \mathrm{H}-{ }^{1} \mathrm{H}$ TOCSY was replaced by ${ }^{1} \mathrm{H}-{ }^{13} \mathrm{C}$ HSQC-TOCSY data. The chemical shifts for $\mathrm{H}-\mathrm{H}$ correlation in the standard mixture were obtained from a database. The ${ }^{13} \mathrm{C}-{ }^{13} \mathrm{C}$ CT-COSY signals were also hardly observed in C. brachypus.

** These pulse programs were modified somewhat to insert a carbon decoupling pulse or the pulse program for proteins was rewritten. 
Supplementary Table S2. Assignments for the standard mixture by database searching and automatic chain assignment.

\begin{tabular}{|c|c|c|c|c|}
\hline Metabolites & ${ }^{1} \mathrm{H}[\mathrm{ppm}]$ & ${ }^{13} \mathrm{C}[\mathrm{ppm}]$ & Database $[\%]^{[\mathrm{a}]}$ & Automatic assignment $[\%]^{[b]}$ \\
\hline Formic acid $(\mathrm{CH})$ & 8.45 & 173.8 & 100 & 100 \\
\hline Pyruvate $\left(\mathrm{CH}_{3}\right)$ & 2.35 & 28.9 & \multirow{3}{*}{100} & \multirow{3}{*}{100} \\
\hline Pyruvate (C) & - & 208.0 & & \\
\hline Pyruvate (C) & - & 173.1 & & \\
\hline Glycerol $\left(\mathrm{CH}_{2}\right)$ & 3.55 & 65.3 & \multirow{3}{*}{$8(1 / 13)$} & \multirow{3}{*}{100} \\
\hline Glycerol (CH) & 3.77 & 74.8 & & \\
\hline$\alpha$-Ketobutyric acid $\left(\mathrm{CH}_{3}\right)$ & 1.05 & 9.2 & & \\
\hline$\alpha$-Ketobutyric acid $\left(\mathrm{CH}_{2}\right)$ & 2.73 & 35.2 & \multirow[t]{3}{*}{$33(1 / 3)$} & \multirow[t]{3}{*}{100} \\
\hline$\alpha$-Ketobutyric acid (C) & - & 211.1 & & \\
\hline$\alpha$-Ketobutyric acid (C) & - & 174.0 & & \\
\hline L-Serine $(\mathrm{CH})$ & 3.83 & 59.0 & \multirow{3}{*}{$20(1 / 5)$} & \multirow{3}{*}{100} \\
\hline L-Serine $\left(\mathrm{CH}_{2}\right)$ & 3.97 & 62.9 & & \\
\hline L-Serine $(C)$ & - & 175.1 & & \\
\hline Fumaric acid $(\mathrm{CH})$ & 6.51 & 138.1 & \multirow{2}{*}{100} & \multirow{2}{*}{100} \\
\hline Fumaric acid (C) & - & 177.5 & & \\
\hline Succinic acid $\left(\mathrm{CH}_{2}\right)$ & 2.39 & 36.9 & \multirow[t]{2}{*}{$25(1 / 4)$} & \multirow[t]{2}{*}{100} \\
\hline Succinic acid (C) & - & 185.1 & & \\
\hline$\beta$-D-Ribose (C1) & 4.92 & 96.5 & \multirow{5}{*}{$6(1 / 17)$} & \multirow{5}{*}{100} \\
\hline$\beta$-D-Ribose (C2) & 3.51 & 73.7 & & \\
\hline$\beta$-D-Ribose (C3) & 4.09 & 71.7 & & \\
\hline$\beta$-D-Ribose (C4) & 3.87 & 70.0 & & \\
\hline$\beta$-D-Ribose (C5) & 3.83 & 65.7 & & \\
\hline$\beta$-D-Xylose (C1) & 4.57 & 99.5 & \multirow{5}{*}{$6(1 / 16)$} & \multirow{4}{*}{100} \\
\hline$\beta$-D-Xylose (C2) & 3.22 & 76.9 & & \\
\hline$\beta$-D-Xylose (C3) & 3.43 & 78.7 & & \\
\hline$\beta$-D-Xylose (C4) & 3.62 & 72.1 & & \\
\hline$\beta$-D-Xylose (C5) & 3.32 & 68.0 & & \multirow{7}{*}{100} \\
\hline$\beta$-D-Galactose (C1) & 4.58 & 99.3 & \multirow{6}{*}{$3(1 / 33)$} & \\
\hline$\beta$-D-Galactose (C2) & 3.49 & 74.7 & & \\
\hline$\beta$-D-Galactose (C3) & 3.66 & 75.7 & & \\
\hline$\beta$-D-Galactose (C4) & 3.92 & 71.6 & & \\
\hline$\beta$-D-Galactose (C5) & 3.71 & 78.0 & & \\
\hline$\beta$-D-Galactose (C6) & 3.75 & 63.8 & & \\
\hline$\beta$-D-Fructose (C1) & 3.70 & 66.3 & \multirow{5}{*}{$4(1 / 26)$} & \multirow{5}{*}{100} \\
\hline$\beta$-D-Fructose (C2) & - & 100.9 & & \\
\hline$\beta$-D-Fructose (C3) & 3.79 & 70.4 & & \\
\hline$\beta$-D-Fructose (C4) & 3.89 & 72.1 & & \\
\hline$\beta$-D-Fructose (C5) & 3.98 & 72.2 & & \\
\hline$\beta$-D-Fructose (C6) & 4.02 & 66.1 & \multirow{7}{*}{$3(1 / 35)$} & \multirow{7}{*}{100} \\
\hline$\beta$-D-Glucose (C1) & 4.64 & 98.8 & & \\
\hline$\beta$-D-Glucose (C2) & 3.24 & 76.9 & & \\
\hline$\beta$-D-Glucose (C3) & 3.46 & 78.8 & & \\
\hline$\beta$-D-Glucose (C4) & 3.40 & 72.4 & & \\
\hline$\beta$-D-Glucose (C5) & 3.48 & 78.6 & & \\
\hline$\beta$-D-Glucose (C6) & 3.72 & 63.6 & & \\
\hline
\end{tabular}

[a] SpinAssign, BMRB, and HMDB were used for database searching. The ratio was calculated as 1/(number of detected metabolites). In the case of $\beta$-D-glucose, 35 metabolites were detected by database searching in SpinAssign, BMRB, and HMDB using all six peaks.

[b] The ratio was calculated regardless of whether the peaks were clustered as one metabolite. All peaks of each compound were clustered by automatic chain assignment. 
Supplementary Table S3. The annotation list for ${ }^{1} \mathrm{H}^{-13} \mathrm{C}$ HSQC and HSQC-TOCSY of C. brachypus by database searching and evaluation of the correlation signals that were confirmed by automatic chain assignment. The reliability of compounds with $100 \%$ correlation signals was verified by quantum chemical calculation. TOCCATA and simple COLMAR HSQC analysis was used for comparison with the method described in this study. The COLMAR HSQC analysis is shown in Figure S4.

\begin{tabular}{|c|c|c|c|c|c|c|c|c|c|}
\hline Metab. No. & Metabolites & Fragments & ${ }^{1} \mathrm{H}[\mathrm{ppm}]{ }^{[\mathrm{a}]}$ & $\left.{ }^{13} \mathrm{C}[\mathrm{ppm}]\right]^{[\mathrm{a}]}$ & $\begin{array}{l}\text { Evaluation } \\
(\mathrm{CH})[\%]^{[\mathrm{b}]}\end{array}$ & $\begin{array}{l}\text { Evaluation } \\
(\mathrm{CH}- \\
\mathrm{CH})[\%]^{[\mathrm{cc}} \\
\end{array}$ & Peak No. ${ }^{[d]}$ & \multicolumn{2}{|c|}{$\begin{array}{l}\text { COLMAR \& } \\
\text { TOCCATA }^{[e]}\end{array}$} \\
\hline 1 & L-Glutamate & $\mathrm{C} 1$ & 3.74 & 57.4 & $100(3 / 3)$ & $100(2 / 2)$ & 71 & $\mathrm{O}$ & 0 \\
\hline 1 & L-Glutamate & $\mathrm{C} 1-\mathrm{C} 2$ & 3.74 & 29.6 & $100(3 / 3)$ & $100(2 / 2)$ & 73 & - & 0 \\
\hline 1 & L-Glutamate & $\mathrm{C} 1-\mathrm{C} 3$ & 3.74 & 36.2 & $100(3 / 3)$ & $100(2 / 2)$ & 72 & - & $\mathrm{O}$ \\
\hline 1 & L-Glutamate & $\mathrm{C} 2$ & 2.11 & 29.6 & $100(3 / 3)$ & $100(2 / 2)$ & 36 & 0 & 0 \\
\hline 1 & L-Glutamate & $\mathrm{C} 2-\mathrm{C} 1$ & 2.11 & 57.4 & $100(3 / 3)$ & $100(2 / 2)$ & 35 & - & 0 \\
\hline 1 & L-Glutamate & $\mathrm{C} 2-\mathrm{C} 3$ & 2.11 & 36.2 & $100(3 / 3)$ & $100(2 / 2)$ & 37 & - & 0 \\
\hline 1 & L-Glutamate & $\mathrm{C} 3$ & 2.34 & 36.2 & $100(3 / 3)$ & $100(2 / 2)$ & 44 & 0 & 0 \\
\hline 1 & L-Glutamate & $\mathrm{C} 3-\mathrm{C} 1$ & 2.34 & 57.4 & $100(3 / 3)$ & $100(2 / 2)$ & 43 & - & $\mathrm{O}$ \\
\hline 1 & L-Glutamate & $\mathrm{C} 3-\mathrm{C} 2$ & 2.34 & 29.6 & $100(3 / 3)$ & $100(2 / 2)$ & 45 & - & 0 \\
\hline 2 & L-Leucine & $\mathrm{C} 1$ & 3.74 & 57.4 & $100(5 / 5)$ & $100(4 / 4)$ & 71 & $\Delta$ & $\Delta$ \\
\hline 2 & L-Leucine & $\mathrm{C} 1-\mathrm{C} 2$ & 1.61 & 57.4 & $100(5 / 5)$ & $100(4 / 4)$ & 19 & - & $\triangle$ \\
\hline 2 & L-Leucine & $\mathrm{C} 2$ & 1.61 & 42.3 & $100(5 / 5)$ & $100(4 / 4)$ & 23 & $\triangle$ & $\triangle$ \\
\hline 2 & L-Leucine & $\mathrm{C} 3-\mathrm{C} 2$ & 1.61 & 27.5 & $100(5 / 5)$ & $100(4 / 4)$ & 22 & - & $\triangle$ \\
\hline 2 & L-Leucine & $\mathrm{C} 5-\mathrm{C} 2$ & 1.61 & 23.5 & $100(5 / 5)$ & $100(4 / 4)$ & 20 & - & $\Delta$ \\
\hline 2 & L-Leucine & $\mathrm{C} 1-\mathrm{C} 3$ & 1.6 & 57.4 & $100(5 / 5)$ & $100(4 / 4)$ & 19 & - & $\Delta$ \\
\hline 2 & L-Leucine & $\mathrm{C} 2-\mathrm{C} 3$ & 1.6 & 42.3 & $100(5 / 5)$ & $100(4 / 4)$ & 23 & - & $\Delta$ \\
\hline 2 & L-Leucine & $\mathrm{C} 3$ & 1.6 & 27.5 & $100(5 / 5)$ & $100(4 / 4)$ & 22 & $\triangle$ & $\Delta$ \\
\hline 2 & L-Leucine & $\mathrm{C} 5-\mathrm{C} 3$ & 1.6 & 23.5 & $100(5 / 5)$ & $100(4 / 4)$ & 20 & - & $\Delta$ \\
\hline 2 & L-Leucine & $\mathrm{C} 2-\mathrm{C} 4$ & 0.93 & 42.3 & $100(5 / 5)$ & $100(4 / 4)$ & 7 & - & $\Delta$ \\
\hline 2 & L-Leucine & $\mathrm{C} 3-\mathrm{C} 4$ & 0.93 & 27.5 & $100(5 / 5)$ & $100(4 / 4)$ & 5 & - & $\triangle$ \\
\hline 2 & L-Leucine & $\mathrm{C} 4$ & 0.93 & 25.2 & $100(5 / 5)$ & $100(4 / 4)$ & 6 & $\triangle$ & $\triangle$ \\
\hline 2 & L-Leucine & $\mathrm{C} 5-\mathrm{C} 4$ & 0.93 & 23.5 & $100(5 / 5)$ & $100(4 / 4)$ & 8 & - & $\Delta$ \\
\hline 2 & L-Leucine & $\mathrm{C} 2-\mathrm{C} 5$ & 0.86 & 42.3 & $100(5 / 5)$ & $100(4 / 4)$ & 3 & - & $\Delta$ \\
\hline 2 & L-Leucine & $\mathrm{C} 3-\mathrm{C} 5$ & 0.86 & 27.5 & $100(5 / 5)$ & $100(4 / 4)$ & 1 & - & $\Delta$ \\
\hline 2 & L-Leucine & $\mathrm{C} 4-\mathrm{C} 5$ & 0.86 & 25.2 & $100(5 / 5)$ & $100(4 / 4)$ & 2 & - & $\Delta$ \\
\hline 2 & L-Leucine & $\mathrm{C} 5$ & 0.86 & 23.5 & $100(5 / 5)$ & $100(4 / 4)$ & 4 & $\Delta$ & $\Delta$ \\
\hline 3 & L-Threonine & $\mathrm{C} 1$ & 3.57 & 64.5 & $100(3 / 3)$ & $100(2 / 2)$ & 66 & $\Delta$ & $\Delta$ \\
\hline 3 & L-Threonine & $\mathrm{C} 2-\mathrm{C} 1$ & 3.57 & 69.8 & $100(3 / 3)$ & $100(2 / 2)$ & 67 & - & $\Delta$ \\
\hline 3 & L-Threonine & $\mathrm{C} 2$ & 4.28 & 69.8 & $100(3 / 3)$ & $100(2 / 2)$ & 81 & $\Delta$ & $\Delta$ \\
\hline 3 & L-Threonine & $\mathrm{C} 3-\mathrm{C} 2$ & 4.28 & 21.6 & $100(3 / 3)$ & $100(2 / 2)$ & 83 & - & $\Delta$ \\
\hline 3 & L-Threonine & $\mathrm{C} 2-\mathrm{C} 3$ & 1.19 & 69.8 & $100(3 / 3)$ & $100(2 / 2)$ & 10 & - & $\triangle$ \\
\hline 3 & L-Threonine & $\mathrm{C} 3$ & 1.19 & 21.6 & $100(3 / 3)$ & $100(2 / 2)$ & 9 & $\Delta$ & $\Delta$ \\
\hline
\end{tabular}

[a] Picked peaks before peak alignment.

[b] Parentheses are the number of correlation signals with hydrogen and carbon that were detected/total number of correlation signals with hydrogen and carbon.

[c] Parentheses are the number of correlation signals with adjacent hydrogen that were detected/total number of correlation signals with adjacent hydrogen.

[d] The peak number is linked to Figure 3a.

[e] The possibility of annotation using COLMAR HSQC (left) and TOCCATA (right) analysis ( $\circ$ : detected, $\triangle$ not detected but the compound is listed in this database, $\times$ : not detected, -: not input. COLMAR requires HSQC signals. $0 \%$ of $\mathrm{CH}-\mathrm{CH}$ evaluation was not used in TOCCATA). 
Supplementary Table S3. Continued

\begin{tabular}{|c|c|c|c|c|c|c|c|c|c|}
\hline Metab. No. & Metabolites & Fragments & $\left.{ }^{1} \mathrm{H}[\mathrm{ppm}]\right]^{[\mathrm{a}]}$ & $\left.{ }^{13} \mathrm{C}[\mathrm{ppm}]\right]^{[\mathrm{a}]}$ & $\begin{array}{l}\text { Evaluation } \\
(\mathrm{CH})[\%]^{[\mathrm{b}]}\end{array}$ & $\begin{array}{l}\text { Evaluation } \\
(\mathrm{CH}- \\
\mathrm{CH})[\%]^{[\mathrm{c}]}\end{array}$ & $\begin{array}{l}\text { Peak } \\
\left.\text { No. }{ }^{[d]}\right]\end{array}$ & \multicolumn{2}{|c|}{$\begin{array}{l}\text { COLMAR \& } \\
\text { TOCCATA }^{\text {ee }}\end{array}$} \\
\hline 4 & L-Alanine & $\mathrm{C} 1$ & 3.67 & 52.3 & $100(2 / 2)$ & $100(1 / 1)$ & 68 & $\Delta$ & $\triangle$ \\
\hline 4 & L-Alanine & $\mathrm{C} 1-\mathrm{C} 2$ & 1.37 & 52.3 & $100(2 / 2)$ & $100(1 / 1)$ & 15 & - & $\triangle$ \\
\hline 4 & L-Alanine & $\mathrm{C} 2$ & 1.37 & 19.7 & $100(2 / 2)$ & $100(1 / 1)$ & 14 & $\Delta$ & $\triangle$ \\
\hline 5 & L-Arginine & $\mathrm{C} 1$ & 3.19 & 43.5 & $100(4 / 4)$ & $100(3 / 3)$ & 64 & $\triangle$ & $\triangle$ \\
\hline 5 & L-Arginine & $\mathrm{C} 2-\mathrm{C} 1$ & 3.19 & 27.6 & $100(4 / 4)$ & $100(3 / 3)$ & 61 & - & $\triangle$ \\
\hline 5 & L-Arginine & $\mathrm{C} 3-\mathrm{C} 1$ & 3.19 & 31.7 & $100(4 / 4)$ & $100(3 / 3)$ & 63 & - & $\triangle$ \\
\hline 5 & L-Arginine & $\mathrm{C} 4-\mathrm{C} 1$ & 3.19 & 57.4 & $100(4 / 4)$ & $100(3 / 3)$ & 60 & - & $\triangle$ \\
\hline 5 & L-Arginine & $\mathrm{C} 1-\mathrm{C} 2$ & 1.6 & 43.5 & $100(4 / 4)$ & $100(3 / 3)$ & 18 & - & $\triangle$ \\
\hline 5 & L-Arginine & $\mathrm{C} 2$ & 1.6 & 27.6 & $100(4 / 4)$ & $100(3 / 3)$ & 22 & $\triangle$ & $\triangle$ \\
\hline 5 & L-Arginine & $\mathrm{C} 3-\mathrm{C} 2$ & 1.6 & 31.7 & $100(4 / 4)$ & $100(3 / 3)$ & 21 & - & $\triangle$ \\
\hline 5 & L-Arginine & $\mathrm{C} 4-\mathrm{C} 2$ & 1.6 & 57.4 & $100(4 / 4)$ & $100(3 / 3)$ & 19 & - & $\triangle$ \\
\hline 5 & L-Arginine & $\mathrm{C} 1-\mathrm{C} 3$ & 1.82 & 43.5 & $100(4 / 4)$ & $100(3 / 3)$ & 26 & - & $\triangle$ \\
\hline 5 & L-Arginine & $\mathrm{C} 2-\mathrm{C} 3$ & 1.82 & 27.6 & $100(4 / 4)$ & $100(3 / 3)$ & 24 & - & $\triangle$ \\
\hline 5 & L-Arginine & $\mathrm{C} 3$ & 1.82 & 31.7 & $100(4 / 4)$ & $100(3 / 3)$ & 27 & $\triangle$ & $\triangle$ \\
\hline 5 & L-Arginine & $\mathrm{C} 4-\mathrm{C} 3$ & 1.82 & 57.4 & $100(4 / 4)$ & $100(3 / 3)$ & 25 & - & $\triangle$ \\
\hline 5 & L-Arginine & $\mathrm{C} 3-\mathrm{C} 4$ & 3.74 & 31.7 & $100(4 / 4)$ & $100(3 / 3)$ & 74 & - & $\triangle$ \\
\hline 5 & L-Arginine & $\mathrm{C} 4$ & 3.74 & 57.4 & $100(4 / 4)$ & $100(3 / 3)$ & 71 & $\triangle$ & $\triangle$ \\
\hline 6 & L-Aspartic acid & $\mathrm{C} 1$ & 3.89 & 54.9 & $100(2 / 2)$ & $100(1 / 1)$ & 77 & $\triangle$ & O \\
\hline 6 & L-Aspartic acid & $\mathrm{C} 2-\mathrm{C} 1$ & 3.89 & 39.1 & $100(2 / 2)$ & $100(1 / 1)$ & 75 & - & O \\
\hline 6 & L-Aspartic acid & $\mathrm{C} 2$ & 2.85 & 39.1 & $100(2 / 2)$ & $100(1 / 1)$ & 52 & $\triangle$ & O \\
\hline 7 & Citrulline & $\mathrm{C} 1$ & 3.74 & 57.4 & $100(4 / 4)$ & $100(3 / 3)$ & 71 & $\triangle$ & $\triangle$ \\
\hline 7 & Citrulline & $\mathrm{C} 2-\mathrm{C} 1$ & 3.74 & 31.6 & $100(4 / 4)$ & $100(3 / 3)$ & 74 & - & $\triangle$ \\
\hline 7 & Citrulline & $\mathrm{C} 1-\mathrm{C} 2$ & 1.82 & 57.4 & $100(4 / 4)$ & $100(3 / 3)$ & 25 & - & $\triangle$ \\
\hline 7 & Citrulline & $\mathrm{C} 2$ & 1.82 & 31.6 & $100(4 / 4)$ & $100(3 / 3)$ & 27 & $\triangle$ & $\triangle$ \\
\hline 7 & Citrulline & $\mathrm{C} 3-\mathrm{C} 2$ & 1.82 & 27.5 & $100(4 / 4)$ & $100(3 / 3)$ & 24 & - & $\triangle$ \\
\hline 7 & Citrulline & $\mathrm{C} 4-\mathrm{C} 2$ & 1.82 & 43.6 & $100(4 / 4)$ & $100(3 / 3)$ & 26 & - & $\triangle$ \\
\hline 7 & Citrulline & $\mathrm{C} 1-\mathrm{C} 3$ & 1.6 & 57.4 & $100(4 / 4)$ & $100(3 / 3)$ & 19 & - & $\triangle$ \\
\hline 7 & Citrulline & $\mathrm{C} 2-\mathrm{C} 3$ & 1.6 & 31.6 & $100(4 / 4)$ & $100(3 / 3)$ & 21 & - & $\triangle$ \\
\hline 7 & Citrulline & $\mathrm{C} 3$ & 1.6 & 27.5 & $100(4 / 4)$ & $100(3 / 3)$ & 22 & $\triangle$ & $\triangle$ \\
\hline 7 & Citrulline & $\mathrm{C} 4-\mathrm{C} 3$ & 1.6 & 43.6 & $100(4 / 4)$ & $100(3 / 3)$ & 18 & - & $\triangle$ \\
\hline 7 & Citrulline & $\mathrm{C} 1-\mathrm{C} 4$ & 3.19 & 57.4 & $100(4 / 4)$ & $100(3 / 3)$ & 60 & - & $\triangle$ \\
\hline 7 & Citrulline & $\mathrm{C} 2-\mathrm{C} 4$ & 3.19 & 31.6 & $100(4 / 4)$ & $100(3 / 3)$ & 63 & - & $\triangle$ \\
\hline 7 & Citrulline & $\mathrm{C} 3-\mathrm{C} 4$ & 3.19 & 27.5 & $100(4 / 4)$ & $100(3 / 3)$ & 61 & - & $\triangle$ \\
\hline 7 & Citrulline & $\mathrm{C} 4$ & 3.19 & 43.6 & $100(4 / 4)$ & $100(3 / 3)$ & 64 & $\triangle$ & $\triangle$ \\
\hline 8 & Methylmalonic acid & $\mathrm{C} 1$ & 3.11 & 55.9 & $100(2 / 2)$ & $100(1 / 1)$ & 59 & $\triangle$ & $\triangle$ \\
\hline 8 & Methylmalonic acid & $\mathrm{C} 1-\mathrm{C} 2$ & 1.28 & 55.9 & $100(2 / 2)$ & $100(1 / 1)$ & 11 & - & $\triangle$ \\
\hline 8 & Methylmalonic acid & $\mathrm{C} 2$ & 1.28 & 19.4 & $100(2 / 2)$ & $100(1 / 1)$ & 12 & $\triangle$ & $\triangle$ \\
\hline 9 & Acetate & $\mathrm{C} 1$ & 1.91 & 26.1 & $100(1 / 1)$ & - & 30 & 0 & O \\
\hline 10 & Pyruvate (Iso.) & $\mathrm{C} 1$ & 1.47 & 28 & $100(1 / 1)$ & - & 16 & 0 & $\mathrm{O}$ \\
\hline 11 & Formate & $\mathrm{C} 1$ & 8.39 & 172.4 & $100(1 / 1)$ & - & - & $\triangle$ & $\triangle$ \\
\hline 12 & Methanol & $\mathrm{C} 1$ & 3.34 & 51.7 & $100(1 / 1)$ & - & 65 & 0 & $\mathrm{O}$ \\
\hline 13 & Phosphoenolpyruvic acid & $\mathrm{C} 1$ & 5.2 & 102.9 & $100(1 / 1)$ & - & - & $\triangle$ & O \\
\hline 14 & Trimethylamine & $\mathrm{C} 1$ & 2.87 & 47.5 & $100(1 / 1)$ & - & 53 & 0 & 0 \\
\hline 15 & Succinate & $\mathrm{C} 1$ & 2.4 & 36.8 & $100(1 / 1)$ & - & 48 & O & O \\
\hline 16 & Malate & $\mathrm{C} 1-\mathrm{C} 2$ & 4.29 & 45.2 & $67(2 / 3)$ & $100(2 / 2)$ & 82 & - & O \\
\hline 16 & Malate & $\mathrm{C} 1-\mathrm{C} 3$ & 4.29 & 45.2 & $67(2 / 3)$ & $100(2 / 2)$ & 82 & - & O \\
\hline 16 & Malate & $\mathrm{C} 2$ & 2.66 & 45.2 & $67(2 / 3)$ & $100(2 / 2)$ & 50 & 0 & O \\
\hline 16 & Malate & $\mathrm{C} 2-\mathrm{C} 3$ & 2.66 & 45.2 & $67(2 / 3)$ & $100(2 / 2)$ & 50 & - & O \\
\hline 16 & Malate & $\mathrm{C} 3$ & 2.36 & 45.4 & $67(2 / 3)$ & $100(2 / 2)$ & 46 & 0 & O \\
\hline 16 & Malate & $\mathrm{C} 3-\mathrm{C} 2$ & 2.36 & 45.4 & $67(2 / 3)$ & $100(2 / 2)$ & 46 & - & O \\
\hline
\end{tabular}


Supplementary Table S3. Continued

\begin{tabular}{|c|c|c|c|c|c|c|c|c|c|}
\hline Metab. No. & Metabolites & Fragments & $\left.{ }^{1} \mathrm{H}[\mathrm{ppm}]\right]^{[\mathrm{a}]}$ & ${ }^{13} \mathrm{C}[\mathrm{ppm}]{ }^{[\mathrm{a}]}$ & $\begin{array}{l}\text { Evaluation } \\
(\mathrm{CH})[\%]^{[b]} \\
\end{array}$ & $\begin{array}{c}\text { Evaluation }(\mathrm{CH}- \\
\mathrm{CH})[\%]^{[\mathrm{cc}]} \\
\end{array}$ & $\begin{array}{l}\text { Peak } \\
\text { No. }{ }^{[\mathrm{d}]} \\
\end{array}$ & \multicolumn{2}{|c|}{$\begin{array}{l}\text { COLMAR \& } \\
\text { TOCCATA }^{[\mathrm{e}]}\end{array}$} \\
\hline 17 & L-Glutamine & $\mathrm{C} 1$ & 3.74 & 57.4 & $67(2 / 3)$ & $50(1 / 2)$ & 71 & $\triangle$ & $\triangle$ \\
\hline 17 & L-Glutamine & $\mathrm{C} 1-\mathrm{C} 2$ & 3.74 & 29.6 & $67(2 / 3)$ & $50(1 / 2)$ & 73 & - & $\triangle$ \\
\hline 17 & L-Glutamine & $\mathrm{C} 2$ & 2.11 & 29.6 & $67(2 / 3)$ & $50(1 / 2)$ & 36 & $\triangle$ & $\triangle$ \\
\hline 17 & L-Glutamine & $\mathrm{C} 2-\mathrm{C} 1$ & 2.11 & 57.4 & $67(2 / 3)$ & $50(1 / 2)$ & 35 & - & $\triangle$ \\
\hline 18 & $N, N$-Dimethylglycine & $\mathrm{C} 1$ & 3.7 & 62.5 & $100(2 / 2)$ & - & 69 & $\mathrm{O}$ & - \\
\hline 18 & $N, N$-Dimethylglycine & $\mathrm{C} 2$ & 2.94 & 45.9 & $100(2 / 2)$ & - & 55 & $\mathrm{O}$ & - \\
\hline 19 & $N$-Acetyl-L-glutamate & $\mathrm{C} 1$ & 4.15 & 57.8 & $100(4 / 4)$ & $100(2 / 2)$ & 80 & $\triangle$ & - \\
\hline 19 & $N$-Acetyl-L-glutamate & $\mathrm{C} 2$ & 2.2 & 36.3 & $100(4 / 4)$ & $100(2 / 2)$ & 41 & $\triangle$ & $\triangle$ \\
\hline 19 & $N$-Acetyl-L-glutamate & $\mathrm{C} 2-\mathrm{C} 4$ & 2.19 & 31.9 & $100(4 / 4)$ & $100(2 / 2)$ & 40 & - & $\triangle$ \\
\hline 19 & $N$-Acetyl-L-glutamate & $\mathrm{C} 3$ & 1.99 & 24.9 & $100(4 / 4)$ & $100(2 / 2)$ & 34 & $\triangle$ & $\triangle$ \\
\hline 19 & $N$-Acetyl-L-glutamate & $\mathrm{C} 3-\mathrm{C} 2$ & 1.99 & 36.3 & $100(4 / 4)$ & $100(2 / 2)$ & 33 & - & $\triangle$ \\
\hline 19 & $N$-Acetyl-L-glutamate & $\mathrm{C} 4$ & 1.86 & 31.5 & $100(4 / 4)$ & $100(2 / 2)$ & 27 & $\triangle$ & $\triangle$ \\
\hline 19 & $N$-Acetyl-L-glutamate & $\mathrm{C} 4-\mathrm{C} 3$ & 1.83 & 25.1 & $100(4 / 4)$ & $100(2 / 2)$ & 28 & - & $\triangle$ \\
\hline 20 & 4-Aminobutanoate & $\mathrm{C} 1$ & 2.98 & 42 & $100(3 / 3)$ & $50(1 / 2)$ & 57 & 0 & $\triangle$ \\
\hline 20 & 4-Aminobutanoate & $\mathrm{C} 2$ & 1.91 & 26.1 & $100(3 / 3)$ & $50(1 / 2)$ & 30 & $\mathrm{O}$ & $\triangle$ \\
\hline 20 & 4-Aminobutanoate & $\mathrm{C} 2-\mathrm{C} 3$ & 1.93 & 36.3 & $100(3 / 3)$ & $50(1 / 2)$ & 29 & - & $\triangle$ \\
\hline 20 & 4-Aminobutanoate & $\mathrm{C} 3$ & 2.26 & 36.4 & $100(3 / 3)$ & $50(1 / 2)$ & 42 & $\triangle$ & $\triangle$ \\
\hline 21 & 6-Carboxyhexanoate & $\mathrm{C} 1$ & 2.17 & 40.4 & $100(3 / 3)$ & $50(1 / 2)$ & 38 & $\mathrm{O}$ & $\triangle$ \\
\hline 21 & 6-Carboxyhexanoate & $\mathrm{C} 1-\mathrm{C} 2$ & 2.17 & 28.6 & $100(3 / 3)$ & $50(1 / 2)$ & 39 & - & $\triangle$ \\
\hline 21 & 6-Carboxyhexanoate & $\mathrm{C} 2$ & 1.53 & 28.6 & $100(3 / 3)$ & $50(1 / 2)$ & 17 & $\mathrm{O}$ & $\triangle$ \\
\hline 21 & 6-Carboxyhexanoate & $\mathrm{C} 3$ & 1.3 & 31 & $100(3 / 3)$ & $50(1 / 2)$ & 13 & O & $\triangle$ \\
\hline 22 & 2-Methylmaleate & $\mathrm{C} 1$ & 1.91 & 23.2 & $50(1 / 2)$ & - & 31 & $x$ & $x$ \\
\hline 23 & 2-Oxoglutarate & $\mathrm{C} 1$ & 3.02 & 38.8 & $100(2 / 2)$ & $0(0 / 1)$ & 58 & $\times$ & - \\
\hline 23 & 2-Oxoglutarate & $\mathrm{C} 2$ & 2.38 & 33.9 & $100(2 / 2)$ & $0(0 / 1)$ & 47 & $\times$ & - \\
\hline 24 & D-threo-Isocitric acid & $\mathrm{C} 1$ & 2.99 & 51.2 & $67(2 / 3)$ & $0(0 / 2)$ & 56 & $\triangle$ & - \\
\hline 24 & D-threo-Isocitric acid & $\mathrm{C} 2$ & 2.49 & 40.5 & $67(2 / 3)$ & $0(0 / 2)$ & 49 & $\triangle$ & - \\
\hline 25 & Choline phosphate & $\mathrm{C} 1$ & 4.14 & 61.3 & $67(2 / 3)$ & $0(0 / 1)$ & 79 & $\triangle$ & - \\
\hline 25 & Choline phosphate & $\mathrm{C} 2$ & 3.2 & 56.1 & $67(2 / 3)$ & $0(0 / 1)$ & 62 & $\triangle$ & - \\
\hline 26 & Ethanolamine phosphate & $\mathrm{C} 1$ & 3.97 & 62.7 & $100(2 / 2)$ & $0(0 / 1)$ & 78 & $\mathrm{O}$ & - \\
\hline 26 & Ethanolamine phosphate & $\mathrm{C} 2$ & 3.2 & 43.5 & $100(2 / 2)$ & $0(0 / 1)$ & 64 & $\mathrm{O}$ & - \\
\hline 27 & Isocitrate & $\mathrm{C} 1$ & 2.92 & 51.5 & $67(2 / 3)$ & $0(0 / 2)$ & 54 & $\times$ & - \\
\hline 27 & Isocitrate & $\mathrm{C} 2$ & 2.49 & 40.5 & $67(2 / 3)$ & $0(0 / 2)$ & 49 & $\times$ & - \\
\hline 28 & 5-Hydroxylysine & $\mathrm{C} 1$ & 3.74 & 57.4 & $80(4 / 5)$ & $0(0 / 4)$ & 71 & $\triangle$ & - \\
\hline 28 & 5-Hydroxylysine & $\mathrm{C} 1-\mathrm{C} 5$ & 3.74 & 47.3 & $80(4 / 5)$ & $0(0 / 4)$ & 70 & - & - \\
\hline 28 & 5-Hydroxylysine & $\mathrm{C} 2$ & 1.94 & 30.3 & $80(4 / 5)$ & $0(0 / 4)$ & 32 & $\triangle$ & - \\
\hline 28 & 5-Hydroxylysine & $\mathrm{C} 3$ & 1.61 & 31.4 & $80(4 / 5)$ & $0(0 / 4)$ & 21 & $\triangle$ & - \\
\hline 28 & 5-Hydroxylysine & $\mathrm{C} 3-\mathrm{C} 1$ & 1.62 & 57.8 & $80(4 / 5)$ & $0(0 / 4)$ & 19 & - & - \\
\hline 28 & 5-Hydroxylysine & $\mathrm{C} 5$ & 2.88 & 47.4 & $80(4 / 5)$ & $0(0 / 4)$ & 53 & $\triangle$ & - \\
\hline 28 & 5-Hydroxylysine & $\mathrm{C} 5-\mathrm{C} 2$ & 2.84 & 30.2 & $80(4 / 5)$ & $0(0 / 4)$ & 51 & - & - \\
\hline 29 & L-Tyrosine & $\mathrm{C} 1$ & 7.1 & 133.2 & $50(2 / 4)$ & $50(1 / 2)$ & - & $\mathrm{O}$ & $\mathrm{O}$ \\
\hline 29 & L-Tyrosine & $\mathrm{C} 2-\mathrm{C} 1$ & 7.1 & 118.2 & $50(2 / 4)$ & $50(1 / 2)$ & - & - & O \\
\hline 29 & L-Tyrosine & $\mathrm{C} 1-\mathrm{C} 2$ & 6.81 & 133.2 & $50(2 / 4)$ & $50(1 / 2)$ & - & - & $\mathrm{O}$ \\
\hline 29 & L-Tyrosine & $\mathrm{C} 2$ & 6.81 & 118.2 & $50(2 / 4)$ & $50(1 / 2)$ & - & O & O \\
\hline 30 & L-Methionine & $\mathrm{C} 1$ & 3.88 & 56.8 & $50(2 / 4)$ & $0(0 / 2)$ & 76 & $\triangle$ & - \\
\hline 30 & L-Methionine & $\mathrm{C} 2$ & 2.18 & 32.2 & $50(2 / 4)$ & $0(0 / 2)$ & 40 & $\triangle$ & - \\
\hline
\end{tabular}


Supplementary Table S4. The annotation list for ${ }^{13} \mathrm{C}-{ }^{13} \mathrm{C}$ TOCSY of $C$. brachypus by database searching and evaluation of the correlation signals that were confirmed by automatic chain assignment. The reliability of the compounds with $100 \%$ correlation signals was verified by quantum chemical calculation.

\begin{tabular}{|c|c|c|c|c|c|c|}
\hline Metab. No. & Metabolites & Fragments & ${ }^{13} \mathrm{C}[\mathrm{ppm}]{ }^{[\mathrm{a}]}$ & $\left.{ }^{13} \mathrm{C}[\mathrm{ppm}]\right]^{[\mathrm{a}]}$ & $\begin{array}{l}\text { Evaluation } \\
(\mathrm{CH}- \\
\mathrm{CH})[\%]^{[b]} \\
\end{array}$ & Peak No. ${ }^{[c]}$ \\
\hline 31 & $\beta$-D-Glucose & $\mathrm{C} 2-\mathrm{C} 1$ & 77 & 98.7 & $100(5 / 5)$ & 138 \\
\hline 31 & $\beta$-D-Glucose & $\mathrm{C} 1-\mathrm{C} 2$ & 98.7 & 77 & $100(5 / 5)$ & 162 \\
\hline 31 & $\beta$-D-Glucose & $\mathrm{C} 3-\mathrm{C} 2$ & 78.6 & 77 & $100(5 / 5)$ & 145 \\
\hline 31 & $\beta$-D-Glucose & $\mathrm{C} 5-\mathrm{C} 2$ & 78.6 & 77 & $100(5 / 5)$ & 145 \\
\hline 31 & $\beta$-D-Glucose & $\mathrm{C} 6-\mathrm{C} 2$ & 63.5 & 77 & $100(5 / 5)$ & 96 \\
\hline 31 & $\beta$-D-Glucose & $\mathrm{C} 2-\mathrm{C} 3$ & 77 & 78.6 & $100(5 / 5)$ & 140 \\
\hline 31 & $\beta$-D-Glucose & $\mathrm{C} 4-\mathrm{C} 3$ & 72.3 & 78.6 & $100(5 / 5)$ & 107 \\
\hline 31 & $\beta$-D-Glucose & $\mathrm{C} 5-\mathrm{C} 3$ & 78.6 & 78.6 & $100(5 / 5)$ & 149 \\
\hline 31 & $\beta$-D-Glucose & C6-C3 & 63.5 & 78.6 & $100(5 / 5)$ & 93 \\
\hline 31 & $\beta$-D-Glucose & $\mathrm{C} 3-\mathrm{C} 4$ & 78.6 & 72.3 & $100(5 / 5)$ & 150 \\
\hline 31 & $\beta$-D-Glucose & $\mathrm{C} 5-\mathrm{C} 4$ & 78.6 & 72.3 & $100(5 / 5)$ & 150 \\
\hline 31 & $\beta$-D-Glucose & $\mathrm{C} 6-\mathrm{C} 4$ & 63.5 & 72.3 & $100(5 / 5)$ & 108 \\
\hline 31 & $\beta$-D-Glucose & $\mathrm{C} 2-\mathrm{C} 5$ & 77 & 78.6 & $100(5 / 5)$ & 140 \\
\hline 31 & $\beta$-D-Glucose & $\mathrm{C} 3-\mathrm{C} 5$ & 78.6 & 78.6 & $100(5 / 5)$ & 149 \\
\hline 31 & $\beta$-D-Glucose & $\mathrm{C} 4-\mathrm{C} 5$ & 72.3 & 78.6 & $100(5 / 5)$ & 107 \\
\hline 31 & $\beta$-D-Glucose & $\mathrm{C} 6-\mathrm{C} 5$ & 63.5 & 78.6 & $100(5 / 5)$ & 93 \\
\hline 31 & $\beta$-D-Glucose & $\mathrm{C} 2-\mathrm{C} 6$ & 77 & 63.5 & $100(5 / 5)$ & 139 \\
\hline 31 & $\beta$-D-Glucose & $\mathrm{C} 3-\mathrm{C} 6$ & 78.6 & 63.5 & $100(5 / 5)$ & 148 \\
\hline 31 & $\beta$-D-Glucose & $\mathrm{C} 5-\mathrm{C} 6$ & 78.6 & 63.5 & $100(5 / 5)$ & 148 \\
\hline 32 & 3-Phospho-D-glycerate & $\mathrm{C} 2-\mathrm{C} 1$ & 75.7 & 69.4 & $100(1 / 1)$ & 132 \\
\hline 32 & 3-Phospho-D-glycerate & $\mathrm{C} 1-\mathrm{C} 2$ & 69.4 & 75.7 & $100(1 / 1)$ & 101 \\
\hline 33 & $\beta$-D-Glucuronate & $\mathrm{C} 2-\mathrm{C} 1$ & 77 & 98.6 & $100(4 / 4)$ & 138 \\
\hline 33 & $\beta$-D-Glucuronate & $\mathrm{C} 1-\mathrm{C} 2$ & 98.6 & 77 & $100(4 / 4)$ & 162 \\
\hline 33 & $\beta$-D-Glucuronate & $\mathrm{C} 4-\mathrm{C} 2$ & 78.3 & 77 & $100(4 / 4)$ & 145 \\
\hline 33 & $\beta$-D-Glucuronate & $\mathrm{C} 5-\mathrm{C} 2$ & 78.8 & 77 & $100(4 / 4)$ & 140 \\
\hline 33 & $\beta$-D-Glucuronate & $\mathrm{C} 2-\mathrm{C} 3$ & 77 & 74.8 & $100(4 / 4)$ & 123 \\
\hline 33 & $\beta$-D-Glucuronate & $\mathrm{C} 2-\mathrm{C} 4$ & 77 & 78.3 & $100(4 / 4)$ & 140 \\
\hline 33 & $\beta$-D-Glucuronate & $\mathrm{C} 3-\mathrm{C} 4$ & 74.8 & 78.3 & $100(4 / 4)$ & 142 \\
\hline 33 & $\beta$-D-Glucuronate & $\mathrm{C} 5-\mathrm{C} 4$ & 78.8 & 78.3 & $100(4 / 4)$ & 149 \\
\hline 33 & $\beta$-D-Glucuronate & $\mathrm{C} 4-\mathrm{C} 5$ & 78.3 & 78.8 & $100(4 / 4)$ & 149 \\
\hline 34 & $\alpha$-D-Glucose & $\mathrm{C} 2-\mathrm{C} 1$ & 74.2 & 94.9 & $100(5 / 5)$ & 161 \\
\hline 34 & $\alpha$-D-Glucose & $\mathrm{C} 5-\mathrm{C} 1$ & 74.2 & 94.9 & $100(5 / 5)$ & 161 \\
\hline 34 & $\alpha$-D-Glucose & $\mathrm{C} 3-\mathrm{C} 2$ & 75.6 & 74.2 & $100(5 / 5)$ & 129 \\
\hline 34 & $\alpha$-D-Glucose & $\mathrm{C} 5-\mathrm{C} 2$ & 74.2 & 74.2 & $100(5 / 5)$ & 115 \\
\hline 34 & $\alpha$-D-Glucose & $\mathrm{C} 6-\mathrm{C} 2$ & 63.4 & 74.2 & $100(5 / 5)$ & 86 \\
\hline 34 & $\alpha$-D-Glucose & $\mathrm{C} 3-\mathrm{C} 3$ & 75.6 & 75.6 & $100(5 / 5)$ & 125 \\
\hline 34 & $\alpha$-D-Glucose & $\mathrm{C} 5-\mathrm{C} 3$ & 74.2 & 75.6 & $100(5 / 5)$ & 114 \\
\hline 34 & $\alpha$-D-Glucose & $\mathrm{C} 6-\mathrm{C} 3$ & 63.4 & 75.6 & $100(5 / 5)$ & 87 \\
\hline
\end{tabular}

[a] Picked peaks before peak alignment.

[b] Parentheses are the number of correlation signals with adjacent carbon that were detected/total number of correlation signals with adjacent carbon without quaternary carbon.

[c] The peak number is linked to Figure $3 \mathrm{~b}$. 
Supplementary Table S4. Continued

\begin{tabular}{|c|c|c|c|c|c|c|}
\hline Metab. No. & Metabolites & Fragments & ${ }^{13} \mathrm{C}[\mathrm{ppm}]{ }^{[\mathrm{a}]}$ & ${ }^{13} \mathrm{C}[\mathrm{ppm}]{ }^{[\mathrm{a}]}$ & $\begin{array}{l}\text { Evaluation } \\
(\mathrm{CH}- \\
\mathrm{CH})[\%]^{[\mathrm{b}]}\end{array}$ & Peak No. ${ }^{[c]}$ \\
\hline 34 & $\alpha$-D-Glucose & $\mathrm{C} 2-\mathrm{C} 4$ & 74.2 & 72.2 & $100(5 / 5)$ & 118 \\
\hline 34 & $\alpha$-D-Glucose & $\mathrm{C} 3-\mathrm{C} 4$ & 75.6 & 72.2 & $100(5 / 5)$ & 127 \\
\hline 34 & $\alpha$-D-Glucose & $\mathrm{C} 5-\mathrm{C} 4$ & 74.2 & 72.2 & $100(5 / 5)$ & 118 \\
\hline 34 & $\alpha$-D-Glucose & $\mathrm{C} 6-\mathrm{C} 4$ & 63.4 & 72.2 & $100(5 / 5)$ & 108 \\
\hline 34 & $\alpha$-D-Glucose & $\mathrm{C} 2-\mathrm{C} 5$ & 74.2 & 74.2 & $100(5 / 5)$ & 115 \\
\hline 34 & $\alpha$-D-Glucose & $\mathrm{C} 3-\mathrm{C} 5$ & 75.6 & 74.2 & $100(5 / 5)$ & 129 \\
\hline 34 & $\alpha$-D-Glucose & $\mathrm{C} 6-\mathrm{C} 5$ & 63.4 & 74.2 & $100(5 / 5)$ & 86 \\
\hline 34 & $\alpha$-D-Glucose & $\mathrm{C} 3-\mathrm{C} 6$ & 75.6 & 63.4 & $100(5 / 5)$ & 130 \\
\hline 35 & L-Fucose & $\mathrm{C} 3-\mathrm{C} 1$ & 73 & 94.8 & $40(2 / 5)$ & 161 \\
\hline 35 & L-Fucose & $\mathrm{C} 4-\mathrm{C} 1$ & 75.6 & 94.8 & $40(2 / 5)$ & 160 \\
\hline 35 & L-Fucose & $\mathrm{C} 5-\mathrm{C} 2$ & 69.7 & 70.9 & $40(2 / 5)$ & 102 \\
\hline 35 & L-Fucose & $\mathrm{C} 4-\mathrm{C} 3$ & 75.6 & 73 & $40(2 / 5)$ & 129 \\
\hline 35 & L-Fucose & $\mathrm{C} 2-\mathrm{C} 4$ & 70.9 & 75.6 & $40(2 / 5)$ & 133 \\
\hline 35 & L-Fucose & $\mathrm{C} 3-\mathrm{C} 4$ & 73 & 75.6 & $40(2 / 5)$ & 110 \\
\hline 35 & L-Fucose & $\mathrm{C} 5-\mathrm{C} 4$ & 69.7 & 75.6 & $40(2 / 5)$ & 101 \\
\hline 35 & L-Fucose & $\mathrm{C} 2-\mathrm{C} 5$ & 70.9 & 69.7 & $40(2 / 5)$ & 104 \\
\hline 35 & L-Fucose & $\mathrm{C} 4-\mathrm{C} 5$ & 75.6 & 69.7 & $40(2 / 5)$ & 132 \\
\hline 36 & D-Sorbitol & $\mathrm{C} 6-\mathrm{C} 1$ & 65.2 & 65.6 & $60(3 / 5)$ & 98 \\
\hline 36 & D-Sorbitol & $\mathrm{C} 3-\mathrm{C} 2$ & 73.8 & 72.5 & $60(3 / 5)$ & 118 \\
\hline 36 & D-Sorbitol & $\mathrm{C} 4-\mathrm{C} 2$ & 73.8 & 72.5 & $60(3 / 5)$ & 118 \\
\hline 36 & D-Sorbitol & $\mathrm{C} 2-\mathrm{C} 3$ & 72.5 & 73.8 & $60(3 / 5)$ & 109 \\
\hline 36 & D-Sorbitol & $\mathrm{C} 4-\mathrm{C} 3$ & 73.8 & 73.8 & $60(3 / 5)$ & 115 \\
\hline 36 & D-Sorbitol & $\mathrm{C} 5-\mathrm{C} 3$ & 75.8 & 73.8 & $60(3 / 5)$ & 129 \\
\hline 36 & D-Sorbitol & $\mathrm{C} 2-\mathrm{C} 4$ & 72.5 & 73.8 & $60(3 / 5)$ & 109 \\
\hline 36 & D-Sorbitol & $\mathrm{C} 3-\mathrm{C} 4$ & 73.8 & 73.8 & $60(3 / 5)$ & 115 \\
\hline 36 & D-Sorbitol & $\mathrm{C} 5-\mathrm{C} 4$ & 75.8 & 73.8 & $60(3 / 5)$ & 129 \\
\hline 36 & D-Sorbitol & $\mathrm{C} 2-\mathrm{C} 5$ & 72.5 & 75.8 & $60(3 / 5)$ & 110 \\
\hline 36 & D-Sorbitol & $\mathrm{C} 3-\mathrm{C} 5$ & 73.8 & 75.8 & $60(3 / 5)$ & 114 \\
\hline 36 & D-Sorbitol & $\mathrm{C} 4-\mathrm{C} 5$ & 73.8 & 75.8 & $60(3 / 5)$ & 114 \\
\hline 36 & D-Sorbitol & $\mathrm{C} 1-\mathrm{C} 6$ & 65.6 & 65.2 & $60(3 / 5)$ & 98 \\
\hline 37 & $\alpha, \alpha$-Trehalose & $\mathrm{C} 3-\mathrm{C} 2$ & 75.4 & 73.8 & $60(3 / 5)$ & 129 \\
\hline 37 & $\alpha, \alpha$-Trehalose & $\mathrm{C} 4-\mathrm{C} 2$ & 72.5 & 73.8 & $60(3 / 5)$ & 109 \\
\hline 37 & $\alpha, \alpha$-Trehalose & $\mathrm{C} 5-\mathrm{C} 2$ & 74.9 & 73.8 & $60(3 / 5)$ & 122 \\
\hline 37 & $\alpha, \alpha$-Trehalose & $\mathrm{C} 6-\mathrm{C} 2$ & 63.3 & 73.8 & $60(3 / 5)$ & 86 \\
\hline 37 & $\alpha, \alpha$-Trehalose & $\mathrm{C} 2-\mathrm{C} 3$ & 73.8 & 75.4 & $60(3 / 5)$ & 114 \\
\hline 37 & $\alpha, \alpha$-Trehalose & $\mathrm{C} 4-\mathrm{C} 3$ & 72.5 & 75.4 & $60(3 / 5)$ & 110 \\
\hline 37 & $\alpha, \alpha$-Trehalose & $\mathrm{C} 5-\mathrm{C} 3$ & 74.9 & 75.4 & $60(3 / 5)$ & 125 \\
\hline 37 & $\alpha, \alpha$-Trehalose & $\mathrm{C} 6-\mathrm{C} 3$ & 63.3 & 75.4 & $60(3 / 5)$ & 87 \\
\hline 37 & $\alpha, \alpha$-Trehalose & $\mathrm{C} 2-\mathrm{C} 4$ & 73.8 & 72.5 & $60(3 / 5)$ & 118 \\
\hline 37 & $\alpha, \alpha$-Trehalose & $\mathrm{C} 6-\mathrm{C} 4$ & 63.3 & 72.5 & $60(3 / 5)$ & 108 \\
\hline 37 & $\alpha, \alpha$-Trehalose & $\mathrm{C} 2-\mathrm{C} 5$ & 73.8 & 74.9 & $60(3 / 5)$ & 112 \\
\hline 37 & $\alpha, \alpha$-Trehalose & $\mathrm{C} 3-\mathrm{C} 5$ & 75.4 & 74.9 & $60(3 / 5)$ & 125 \\
\hline 37 & $\alpha, \alpha$-Trehalose & $\mathrm{C} 6-\mathrm{C} 5$ & 63.3 & 74.9 & $60(3 / 5)$ & 87 \\
\hline 37 & $\alpha, \alpha$-Trehalose & $\mathrm{C} 2-\mathrm{C} 6$ & 73.8 & 63.3 & $60(3 / 5)$ & 113 \\
\hline 37 & $\alpha, \alpha$-Trehalose & $\mathrm{C} 3-\mathrm{C} 6$ & 75.4 & 63.3 & $60(3 / 5)$ & 126 \\
\hline
\end{tabular}




\begin{tabular}{ccccccc}
37 & $\alpha, \alpha$-Trehalose & C5-C6 & 74.9 & 63.3 & $60(3 / 5)$ & $\mathbf{1 2 4}$ \\
38 & D-Xylulose & C3-C1 & 78.9 & 72.4 & $50(1 / 2)$ & $\mathbf{1 5 0}$ \\
\hline
\end{tabular}

Supplementary Table S4. Continued

\begin{tabular}{|c|c|c|c|c|c|c|}
\hline Metab. No. & Metabolites & Fragments & ${ }^{13} \mathrm{C}[\mathrm{ppm}]{ }^{[\mathrm{a}]}$ & ${ }^{13} \mathrm{C}[\mathrm{ppm}]{ }^{[\mathrm{a}]}$ & $\begin{array}{c}\text { Evaluation } \\
(\mathrm{CH}- \\
\mathrm{CH})[\%]^{[\mathrm{b}]} \\
\end{array}$ & Peak No. ${ }^{[\mathrm{c}]}$ \\
\hline 38 & D-Xylulose & $\mathrm{C} 3-\mathrm{C} 2$ & 78.9 & 77.5 & $50(1 / 2)$ & 140 \\
\hline 39 & $\beta$-D-Ribose 5-phosphate & $\mathrm{C} 2-\mathrm{C} 1$ & 78.3 & 103 & $50(2 / 4)$ & 144 \\
\hline 39 & $\beta$-D-Ribose 5-phosphate & $\mathrm{C} 3-\mathrm{C} 1$ & 73.2 & 103 & $50(2 / 4)$ & 111 \\
\hline 39 & $\beta$-D-Ribose 5-phosphate & $\mathrm{C} 1-\mathrm{C} 2$ & 103 & 78.3 & $50(2 / 4)$ & 169 \\
\hline 39 & $\beta$-D-Ribose 5-phosphate & $\mathrm{C} 1-\mathrm{C} 3$ & 103 & 73.2 & $50(2 / 4)$ & 168 \\
\hline 39 & $\beta$-D-Ribose 5-phosphate & $\mathrm{C} 4-\mathrm{C} 3$ & 84.4 & 73.2 & $50(2 / 4)$ & 157 \\
\hline 40 & $\beta$-D-Ribofuranose & $\mathrm{C} 2-\mathrm{C} 1$ & 78.1 & 103.2 & $50(2 / 4)$ & 144 \\
\hline 40 & $\beta$-D-Ribofuranose & $\mathrm{C} 3-\mathrm{C} 1$ & 73.1 & 103.2 & $50(2 / 4)$ & 111 \\
\hline 40 & $\beta$-D-Ribofuranose & $\mathrm{C} 1-\mathrm{C} 2$ & 103.2 & 78.1 & $50(2 / 4)$ & 169 \\
\hline 40 & $\beta$-D-Ribofuranose & $\mathrm{C} 4-\mathrm{C} 2$ & 85.1 & 78.1 & $50(2 / 4)$ & 159 \\
\hline 40 & $\beta$-D-Ribofuranose & $\mathrm{C} 1-\mathrm{C} 3$ & 103.2 & 73.1 & $50(2 / 4)$ & 168 \\
\hline 40 & $\beta$-D-Ribofuranose & $\mathrm{C} 4-\mathrm{C} 3$ & 85.1 & 73.1 & $50(2 / 4)$ & 158 \\
\hline 41 & Sucrose & $\mathrm{C} 1-\mathrm{C} 2$ & 94.8 & 73.8 & $63(5 / 8)$ & 161 \\
\hline 41 & Sucrose & $\mathrm{C} 6-\mathrm{C} 2$ & 62.8 & 73.8 & $63(5 / 8)$ & 86 \\
\hline 41 & Sucrose & $\mathrm{C} 4-\mathrm{C} 3$ & 72 & 75.6 & $63(5 / 8)$ & 106 \\
\hline 41 & Sucrose & $\mathrm{C} 6-\mathrm{C} 3$ & 62.8 & 75.6 & $63(5 / 8)$ & 87 \\
\hline 41 & Sucrose & $\mathrm{C} 2-\mathrm{C} 4$ & 73.8 & 72 & $63(5 / 8)$ & 118 \\
\hline 41 & Sucrose & $\mathrm{C} 5-\mathrm{C} 4$ & 75.4 & 72 & $63(5 / 8)$ & 127 \\
\hline 41 & Sucrose & $\mathrm{C} 4-\mathrm{C} 5$ & 72 & 75.4 & $63(5 / 8)$ & 106 \\
\hline 41 & Sucrose & C6-C5 & 62.8 & 75.4 & $63(5 / 8)$ & 87 \\
\hline 41 & Sucrose & $\mathrm{C} 2-\mathrm{C} 6$ & 73.8 & 62.8 & $63(5 / 8)$ & 113 \\
\hline 41 & Sucrose & $\mathrm{C} 3-\mathrm{C} 6$ & 75.6 & 62.8 & $63(5 / 8)$ & 130 \\
\hline 41 & Sucrose & C5-C6 & 75.4 & 62.8 & $63(5 / 8)$ & 126 \\
\hline 41 & Sucrose & $\mathrm{C} 7-\mathrm{C} 8$ & 79.9 & 76.8 & $63(5 / 8)$ & 153 \\
\hline 42 & $\beta$-D-Maltose & $\mathrm{C} 2-\mathrm{C} 1$ & 76.8 & 98.5 & $70(7 / 10)$ & 138 \\
\hline 42 & $\beta$-D-Maltose & $\mathrm{C} 3-\mathrm{C} 2$ & 79.1 & 76.8 & $70(7 / 10)$ & 153 \\
\hline 42 & $\beta$-D-Maltose & $\mathrm{C} 4-\mathrm{C} 2$ & 79.4 & 76.8 & $70(7 / 10)$ & 153 \\
\hline 42 & $\beta$-D-Maltose & $\mathrm{C} 6-\mathrm{C} 3$ & 63.3 & 79.1 & $70(7 / 10)$ & 89 \\
\hline 42 & $\beta$-D-Maltose & C6-C4 & 63.3 & 79.4 & $70(7 / 10)$ & 89 \\
\hline 42 & $\beta$-D-Maltose & $\mathrm{C} 6-\mathrm{C} 5$ & 63.3 & 77.7 & $70(7 / 10)$ & 92 \\
\hline 42 & $\beta$-D-Maltose & C3-C6 & 79.1 & 63.3 & $70(7 / 10)$ & 151 \\
\hline 42 & $\beta$-D-Maltose & $\mathrm{C} 4-\mathrm{C} 6$ & 79.4 & 63.3 & $70(7 / 10)$ & 151 \\
\hline 42 & $\beta$-D-Maltose & C5-C6 & 77.7 & 63.3 & $70(7 / 10)$ & 141 \\
\hline 42 & $\beta$-D-Maltose & $\mathrm{C} 8-\mathrm{C} 7$ & 74.4 & 102.3 & $70(7 / 10)$ & 117 \\
\hline 42 & $\beta$-D-Maltose & C9-C7 & 75.7 & 102.3 & $70(7 / 10)$ & 128 \\
\hline 42 & $\beta$-D-Maltose & $\mathrm{C} 11-\mathrm{C} 7$ & 75.4 & 102.3 & $70(7 / 10)$ & 128 \\
\hline 42 & $\beta$-D-Maltose & $\mathrm{C} 7-\mathrm{C} 8$ & 102.3 & 74.4 & $70(7 / 10)$ & 166 \\
\hline 42 & $\beta$-D-Maltose & $\mathrm{C} 7-\mathrm{C} 9$ & 102.3 & 75.7 & $70(7 / 10)$ & 167 \\
\hline 42 & $\beta$-D-Maltose & $\mathrm{C} 10-\mathrm{C} 9$ & 72.1 & 75.7 & $70(7 / 10)$ & 106 \\
\hline 42 & $\beta$-D-Maltose & $\mathrm{C} 12-\mathrm{C} 9$ & 63.3 & 75.7 & $70(7 / 10)$ & 87 \\
\hline 42 & $\beta$-D-Maltose & $\mathrm{C} 7-\mathrm{C} 10$ & 102.3 & 72.1 & $70(7 / 10)$ & 165 \\
\hline 42 & $\beta$-D-Maltose & C $8-\mathrm{C} 10$ & 74.4 & 72.1 & $70(7 / 10)$ & 118 \\
\hline 42 & $\beta$-D-Maltose & $\mathrm{C} 11-\mathrm{C} 10$ & 75.4 & 72.1 & $70(7 / 10)$ & 127 \\
\hline 42 & $\beta$-D-Maltose & C7-C11 & 102.3 & 75.4 & $70(7 / 10)$ & 167 \\
\hline
\end{tabular}




\begin{tabular}{cccccccc}
42 & $\beta$-D-Maltose & $\mathrm{C} 10-\mathrm{C} 11$ & 72.1 & 75.4 & $70(7 / 10)$ & $\mathbf{1 0 6}$ & $\mathbf{8 7}$ \\
42 & $\beta$-D-Maltose & $\mathrm{C} 12-\mathrm{C} 11$ & 63.3 & 75.4 & $70(7 / 10)$ & $\mathbf{8 7}$ \\
42 & $\beta$-D-Maltose & $\mathrm{C} 7-\mathrm{C} 12$ & 102.3 & 63.3 & $70(7 / 10)$ & $\mathbf{1 6 4}$ & \\
\hline
\end{tabular}

Supplementary Table S4. Continued

\begin{tabular}{|c|c|c|c|c|c|c|}
\hline Metab. No. & Metabolites & Fragments & $\left.{ }^{13} \mathrm{C}[\mathrm{ppm}]\right]^{[\mathrm{a}]}$ & $\left.{ }^{13} \mathrm{C}[\mathrm{ppm}]\right]^{[\mathrm{a}]}$ & $\begin{array}{c}\text { Evaluation } \\
(\mathrm{CH}- \\
\mathrm{CH})[\%]^{[\mathrm{b}]} \\
\end{array}$ & Peak No. ${ }^{[c]}$ \\
\hline 42 & $\beta$-D-Maltose & C8-C12 & 74.4 & 63.3 & $70(7 / 10)$ & 120 \\
\hline 42 & $\beta$-D-Maltose & C9-C12 & 75.7 & 63.3 & $70(7 / 10)$ & 130 \\
\hline 42 & $\beta$-D-Maltose & $\mathrm{C} 11-\mathrm{C} 12$ & 75.4 & 63.3 & $70(7 / 10)$ & 126 \\
\hline 43 & $\alpha$-D-Maltose & $\mathrm{C} 1-\mathrm{C} 2$ & 94.6 & 74.4 & $70(7 / 10)$ & 161 \\
\hline 43 & $\alpha$-D-Maltose & $\mathrm{C} 4-\mathrm{C} 2$ & 79.4 & 74.4 & $70(7 / 10)$ & 152 \\
\hline 43 & $\alpha$-D-Maltose & $\mathrm{C} 6-\mathrm{C} 2$ & 63.2 & 74.4 & $70(7 / 10)$ & 86 \\
\hline 43 & $\alpha$-D-Maltose & $\mathrm{C} 4-\mathrm{C} 3$ & 79.4 & 76 & $70(7 / 10)$ & 153 \\
\hline 43 & $\alpha$-D-Maltose & $\mathrm{C} 5-\mathrm{C} 3$ & 71.9 & 76 & $70(7 / 10)$ & 106 \\
\hline 43 & $\alpha$-D-Maltose & $\mathrm{C} 6-\mathrm{C} 3$ & 63.2 & 76 & $70(7 / 10)$ & 87 \\
\hline 43 & $\alpha$-D-Maltose & $\mathrm{C} 2-\mathrm{C} 4$ & 74.4 & 79.4 & $70(7 / 10)$ & 119 \\
\hline 43 & $\alpha$-D-Maltose & $\mathrm{C} 3-\mathrm{C} 4$ & 76 & 79.4 & $70(7 / 10)$ & 131 \\
\hline 43 & $\alpha$-D-Maltose & $\mathrm{C} 5-\mathrm{C} 4$ & 71.9 & 79.4 & $70(7 / 10)$ & 154 \\
\hline 43 & $\alpha$-D-Maltose & $\mathrm{C} 6-\mathrm{C} 4$ & 63.2 & 79.4 & $70(7 / 10)$ & 89 \\
\hline 43 & $\alpha$-D-Maltose & $\mathrm{C} 2-\mathrm{C} 5$ & 74.4 & 71.9 & $70(7 / 10)$ & 118 \\
\hline 43 & $\alpha$-D-Maltose & $\mathrm{C} 4-\mathrm{C} 5$ & 79.4 & 71.9 & $70(7 / 10)$ & 154 \\
\hline 43 & $\alpha$-D-Maltose & $\mathrm{C} 2-\mathrm{C} 6$ & 74.4 & 63.2 & $70(7 / 10)$ & 120 \\
\hline 43 & $\alpha$-D-Maltose & $\mathrm{C} 3-\mathrm{C} 6$ & 76 & 63.2 & $70(7 / 10)$ & 130 \\
\hline 43 & $\alpha$-D-Maltose & $\mathrm{C} 4-\mathrm{C} 6$ & 79.4 & 63.2 & $70(7 / 10)$ & 151 \\
\hline 43 & $\alpha$-D-Maltose & $\mathrm{C} 8-\mathrm{C} 7$ & 74.4 & 102.3 & $70(7 / 10)$ & 117 \\
\hline 43 & $\alpha$-D-Maltose & $\mathrm{C} 9-\mathrm{C} 7$ & 75.7 & 102.3 & $70(7 / 10)$ & 128 \\
\hline 43 & $\alpha$-D-Maltose & C11-C7 & 75.4 & 102.3 & $70(7 / 10)$ & 128 \\
\hline 43 & $\alpha$-D-Maltose & $\mathrm{C} 7-\mathrm{C} 8$ & 102.3 & 74.4 & $70(7 / 10)$ & 166 \\
\hline 43 & $\alpha$-D-Maltose & C7-C9 & 102.3 & 75.7 & $70(7 / 10)$ & 167 \\
\hline 43 & $\alpha$-D-Maltose & $\mathrm{C} 10-\mathrm{C} 9$ & 72.1 & 75.7 & $70(7 / 10)$ & 106 \\
\hline 43 & $\alpha$-D-Maltose & $\mathrm{C} 12-\mathrm{C} 9$ & 63.3 & 75.7 & $70(7 / 10)$ & 87 \\
\hline 43 & $\alpha$-D-Maltose & C7-C10 & 102.3 & 72.1 & $70(7 / 10)$ & 165 \\
\hline 43 & $\alpha$-D-Maltose & $\mathrm{C} 8-\mathrm{C} 10$ & 74.4 & 72.1 & $70(7 / 10)$ & 118 \\
\hline 43 & $\alpha$-D-Maltose & $\mathrm{C} 11-\mathrm{C} 10$ & 75.4 & 72.1 & $70(7 / 10)$ & 127 \\
\hline 43 & $\alpha$-D-Maltose & C7-C11 & 102.3 & 75.4 & $70(7 / 10)$ & 167 \\
\hline 43 & $\alpha$-D-Maltose & $\mathrm{C} 10-\mathrm{C} 11$ & 72.1 & 75.4 & $70(7 / 10)$ & 106 \\
\hline 43 & $\alpha$-D-Maltose & $\mathrm{C} 12-\mathrm{C} 11$ & 63.3 & 75.4 & $70(7 / 10)$ & 87 \\
\hline 43 & $\alpha$-D-Maltose & $\mathrm{C} 7-\mathrm{C} 12$ & 102.3 & 63.3 & $70(7 / 10)$ & 164 \\
\hline 43 & $\alpha$-D-Maltose & $\mathrm{C} 8-\mathrm{C} 12$ & 74.4 & 63.3 & $70(7 / 10)$ & 120 \\
\hline 43 & $\alpha$-D-Maltose & C9-C12 & 75.7 & 63.3 & $70(7 / 10)$ & 130 \\
\hline 43 & $\alpha$-D-Maltose & $\mathrm{C} 11-\mathrm{C} 12$ & 75.4 & 63.3 & $70(7 / 10)$ & 126 \\
\hline 44 & $\alpha$-Cellobiose & $\mathrm{C} 1-\mathrm{C} 2$ & 94.5 & 73.9 & $70(7 / 10)$ & 161 \\
\hline 44 & $\alpha$-Cellobiose & $\mathrm{C} 4-\mathrm{C} 2$ & 81.3 & 73.9 & $70(7 / 10)$ & 156 \\
\hline 44 & $\alpha$-Cellobiose & $\mathrm{C} 6-\mathrm{C} 2$ & 63.2 & 73.9 & $70(7 / 10)$ & 86 \\
\hline 44 & $\alpha$-Cellobiose & $\mathrm{C} 1-\mathrm{C} 3$ & 94.5 & 74 & $70(7 / 10)$ & 161 \\
\hline 44 & $\alpha$-Cellobiose & $\mathrm{C} 4-\mathrm{C} 3$ & 81.3 & 74 & $70(7 / 10)$ & 156 \\
\hline 44 & $\alpha$-Cellobiose & $\mathrm{C} 6-\mathrm{C} 3$ & 63.2 & 74 & $70(7 / 10)$ & 86 \\
\hline 44 & $\alpha$-Cellobiose & $\mathrm{C} 2-\mathrm{C} 4$ & 73.9 & 81.3 & $70(7 / 10)$ & 156 \\
\hline 44 & $\alpha$-Cellobiose & $\mathrm{C} 3-\mathrm{C} 4$ & 74 & 81.3 & $70(7 / 10)$ & 156 \\
\hline
\end{tabular}




\begin{tabular}{cccccccc}
44 & $\alpha$-Cellobiose & C6-C4 & 63.2 & 81.3 & $70(7 / 10)$ & $\mathbf{8 8}$ & $\mathbf{1 1 8}$ \\
44 & $\alpha$-Cellobiose & C2-C5 & 73.9 & 72 & $70(7 / 10)$ & $70(7 / 10)$ & $\mathbf{1 1 8}$ \\
44 & $\alpha$-Cellobiose & C3-C5 & 74 & 72 & 63.2 & $70(7 / 10)$ & $\mathbf{1 1 3}$ \\
\hline
\end{tabular}

Supplementary Table S4. Continued

\begin{tabular}{|c|c|c|c|c|c|c|}
\hline Metab. No. & Metabolites & Fragments & ${ }^{13} \mathrm{C}[\mathrm{ppm}]{ }^{[\mathrm{a}]}$ & ${ }^{13} \mathrm{C}[\mathrm{ppm}]{ }^{[\mathrm{a}]}$ & $\begin{array}{l}\text { Evaluation } \\
(\mathrm{CH}- \\
\mathrm{CH})[\%]^{[b]} \\
\end{array}$ & Peak No. ${ }^{[c]}$ \\
\hline 44 & $\alpha$-Cellobiose & C3-C6 & 74 & 63.2 & $70(7 / 10)$ & 113 \\
\hline 44 & $\alpha$-Cellobiose & $\mathrm{C} 8-\mathrm{C} 7$ & 75.9 & 104.3 & $70(7 / 10)$ & 136 \\
\hline 44 & $\alpha$-Cellobiose & $\mathrm{C} 9-\mathrm{C} 7$ & 78.3 & 104.3 & $70(7 / 10)$ & 147 \\
\hline 44 & $\alpha$-Cellobiose & $\mathrm{C} 11-\mathrm{C} 7$ & 78.6 & 104.3 & $70(7 / 10)$ & 147 \\
\hline 44 & $\alpha$-Cellobiose & $\mathrm{C} 12-\mathrm{C} 7$ & 63.3 & 104.3 & $70(7 / 10)$ & 91 \\
\hline 44 & $\alpha$-Cellobiose & $\mathrm{C} 7-\mathrm{C} 8$ & 104.3 & 75.9 & $70(7 / 10)$ & 172 \\
\hline 44 & $\alpha$-Cellobiose & $\mathrm{C} 9-\mathrm{C} 8$ & 78.3 & 75.9 & $70(7 / 10)$ & 143 \\
\hline 44 & $\alpha$-Cellobiose & $\mathrm{C} 10-\mathrm{C} 8$ & 72.2 & 75.9 & $70(7 / 10)$ & 106 \\
\hline 44 & $\alpha$-Cellobiose & $\mathrm{C} 11-\mathrm{C} 8$ & 78.6 & 75.9 & $70(7 / 10)$ & 143 \\
\hline 44 & $\alpha$-Cellobiose & $\mathrm{C} 12-\mathrm{C} 8$ & 63.3 & 75.9 & $70(7 / 10)$ & 87 \\
\hline 44 & $\alpha$-Cellobiose & $\mathrm{C} 7-\mathrm{C} 9$ & 104.3 & 78.3 & $70(7 / 10)$ & 170 \\
\hline 44 & $\alpha$-Cellobiose & $\mathrm{C} 8-\mathrm{C} 9$ & 75.9 & 78.3 & $70(7 / 10)$ & 131 \\
\hline 44 & $\alpha$-Cellobiose & $\mathrm{C} 10-\mathrm{C} 9$ & 72.2 & 78.3 & $70(7 / 10)$ & 107 \\
\hline 44 & $\alpha$-Cellobiose & $\mathrm{C} 12-\mathrm{C} 9$ & 63.3 & 78.3 & $70(7 / 10)$ & 93 \\
\hline 44 & $\alpha$-Cellobiose & $\mathrm{C} 11-\mathrm{C} 10$ & 78.6 & 72.2 & $70(7 / 10)$ & 150 \\
\hline 44 & $\alpha$-Cellobiose & C7-C11 & 104.3 & 78.6 & $70(7 / 10)$ & 170 \\
\hline 44 & $\alpha$-Cellobiose & C8-C11 & 75.9 & 78.6 & $70(7 / 10)$ & 131 \\
\hline 44 & $\alpha$-Cellobiose & $\mathrm{C} 10-\mathrm{C} 11$ & 72.2 & 78.6 & $70(7 / 10)$ & 107 \\
\hline 44 & $\alpha$-Cellobiose & $\mathrm{C} 12-\mathrm{C} 11$ & 63.3 & 78.6 & $70(7 / 10)$ & 93 \\
\hline 44 & $\alpha$-Cellobiose & $\mathrm{C} 7-\mathrm{C} 12$ & 104.3 & 63.3 & $70(7 / 10)$ & 171 \\
\hline 44 & $\alpha$-Cellobiose & $\mathrm{C} 8-\mathrm{C} 12$ & 75.9 & 63.3 & $70(7 / 10)$ & 130 \\
\hline 44 & $\alpha$-Cellobiose & C9-C12 & 78.3 & 63.3 & $70(7 / 10)$ & 148 \\
\hline 44 & $\alpha$-Cellobiose & $\mathrm{C} 10-\mathrm{C} 12$ & 72.2 & 63.3 & $70(7 / 10)$ & 108 \\
\hline 44 & $\alpha$-Cellobiose & $\mathrm{C} 11-\mathrm{C} 12$ & 78.6 & 63.3 & $70(7 / 10)$ & 148 \\
\hline 44 & $\alpha$-Cellobiose & $\mathrm{C} 8-\mathrm{C} 7$ & 75.9 & 105.2 & $70(7 / 10)$ & 135 \\
\hline 44 & $\alpha$-Cellobiose & $\mathrm{C} 9-\mathrm{C} 7$ & 78.3 & 105.2 & $70(7 / 10)$ & 146 \\
\hline 44 & $\alpha$-Cellobiose & C11-C7 & 78.6 & 105.2 & $70(7 / 10)$ & 146 \\
\hline 44 & $\alpha$-Cellobiose & $\mathrm{C} 12-\mathrm{C} 7$ & 63.3 & 105.2 & $70(7 / 10)$ & 90 \\
\hline 44 & $\alpha$-Cellobiose & $\mathrm{C} 7-\mathrm{C} 8$ & 105.2 & 75.9 & $70(7 / 10)$ & 174 \\
\hline 44 & $\alpha$-Cellobiose & $\mathrm{C} 12-\mathrm{C} 8$ & 63.3 & 75.9 & $70(7 / 10)$ & 87 \\
\hline 44 & $\alpha$-Cellobiose & C7-C9 & 105.2 & 78.3 & $70(7 / 10)$ & 173 \\
\hline 44 & $\alpha$-Cellobiose & $\mathrm{C} 12-\mathrm{C} 9$ & 63.3 & 78.3 & $70(7 / 10)$ & 93 \\
\hline 44 & $\alpha$-Cellobiose & C7-C10 & 105.2 & 72.2 & $70(7 / 10)$ & 176 \\
\hline 44 & $\alpha$-Cellobiose & C7-C11 & 105.2 & 78.6 & $70(7 / 10)$ & 173 \\
\hline 44 & $\alpha$-Cellobiose & $\mathrm{C} 12-\mathrm{C} 11$ & 63.3 & 78.6 & $70(7 / 10)$ & 93 \\
\hline 44 & $\alpha$-Cellobiose & $\mathrm{C} 7-\mathrm{C} 12$ & 105.2 & 63.3 & $70(7 / 10)$ & 175 \\
\hline 44 & $\alpha$-Cellobiose & $\mathrm{C} 8-\mathrm{C} 12$ & 75.9 & 63.3 & $70(7 / 10)$ & 130 \\
\hline 44 & $\alpha$-Cellobiose & C9-C12 & 78.3 & 63.3 & $70(7 / 10)$ & 148 \\
\hline 44 & $\alpha$-Cellobiose & $\mathrm{C} 10-\mathrm{C} 12$ & 72.2 & 63.3 & $70(7 / 10)$ & 108 \\
\hline 44 & $\alpha$-Cellobiose & $\mathrm{C} 11-\mathrm{C} 12$ & 78.6 & 63.3 & $70(7 / 10)$ & 148 \\
\hline 45 & $\beta$-Cellobiose & $\mathrm{C} 2-\mathrm{C} 1$ & 76.6 & 98.4 & $70(7 / 10)$ & 138 \\
\hline 45 & $\beta$-Cellobiose & $\mathrm{C} 3-\mathrm{C} 1$ & 76.7 & 98.4 & $70(7 / 10)$ & 138 \\
\hline
\end{tabular}




\begin{tabular}{|c|c|c|c|c|c|c|}
\hline 45 & $\beta$-Cellobiose & $\mathrm{C} 6-\mathrm{C} 2$ & 62.8 & 76.6 & $70(7 / 10)$ & 84 \\
\hline 45 & $\beta$-Cellobiose & $\mathrm{C} 6-\mathrm{C} 3$ & 62.8 & 76.7 & $70(7 / 10)$ & 84 \\
\hline 45 & $\beta$-Cellobiose & $\mathrm{C} 6-\mathrm{C} 5$ & 62.8 & 77.7 & $70(7 / 10)$ & 85 \\
\hline 45 & $\beta$-Cellobiose & $\mathrm{C} 4-\mathrm{C} 6$ & 81.3 & 62.8 & $70(7 / 10)$ & 155 \\
\hline 45 & $\beta$-Cellobiose & $\mathrm{C} 5-\mathrm{C} 6$ & 77.7 & 62.8 & $70(7 / 10)$ & 141 \\
\hline
\end{tabular}

Supplementary Table S4. Continued

\begin{tabular}{|c|c|c|c|c|c|c|}
\hline Metab. No. & Metabolites & Fragments & ${ }^{13} \mathrm{C}[\mathrm{ppm}]{ }^{[\mathrm{a}]}$ & ${ }^{13} \mathrm{C}[\mathrm{ppm}]{ }^{[\mathrm{a}]}$ & $\begin{array}{c}\text { Evaluation } \\
(\mathrm{CH}-\mathrm{CH})[\%]^{[\mathrm{b}]}\end{array}$ & Peak No. ${ }^{[\mathrm{c}]}$ \\
\hline 45 & $\beta$-Cellobiose & $\mathrm{C} 6-\mathrm{C} 2$ & 62.8 & 76.6 & $70(7 / 10)$ & 84 \\
\hline 45 & $\beta$-Cellobiose & $\mathrm{C} 6-\mathrm{C} 3$ & 62.8 & 76.7 & $70(7 / 10)$ & 84 \\
\hline 45 & $\beta$-Cellobiose & $\mathrm{C} 6-\mathrm{C} 5$ & 62.8 & 77.7 & $70(7 / 10)$ & 85 \\
\hline 45 & $\beta$-Cellobiose & $\mathrm{C} 4-\mathrm{C} 6$ & 81.3 & 62.8 & $70(7 / 10)$ & 155 \\
\hline 45 & $\beta$-Cellobiose & $\mathrm{C} 5-\mathrm{C} 6$ & 77.7 & 62.8 & $70(7 / 10)$ & 141 \\
\hline 45 & $\beta$-Cellobiose & $\mathrm{C} 8-\mathrm{C} 7$ & 75.9 & 104.3 & $70(7 / 10)$ & 136 \\
\hline 45 & $\beta$-Cellobiose & $\mathrm{C} 9-\mathrm{C} 7$ & 78.3 & 104.3 & $70(7 / 10)$ & 147 \\
\hline 45 & $\beta$-Cellobiose & C11-C7 & 78.6 & 104.3 & $70(7 / 10)$ & 147 \\
\hline 45 & $\beta$-Cellobiose & $\mathrm{C} 12-\mathrm{C} 7$ & 63.3 & 104.3 & $70(7 / 10)$ & 91 \\
\hline 45 & $\beta$-Cellobiose & $\mathrm{C} 7-\mathrm{C} 8$ & 104.3 & 75.9 & $70(7 / 10)$ & 172 \\
\hline 45 & $\beta$-Cellobiose & C9-C8 & 78.3 & 75.9 & $70(7 / 10)$ & 143 \\
\hline 45 & $\beta$-Cellobiose & $\mathrm{C} 10-\mathrm{C} 8$ & 72.2 & 75.9 & $70(7 / 10)$ & 106 \\
\hline 45 & $\beta$-Cellobiose & C11-C8 & 78.6 & 75.9 & $70(7 / 10)$ & 143 \\
\hline 45 & $\beta$-Cellobiose & $\mathrm{C} 12-\mathrm{C} 8$ & 63.3 & 75.9 & $70(7 / 10)$ & 87 \\
\hline 45 & $\beta$-Cellobiose & $\mathrm{C} 7-\mathrm{C} 9$ & 104.3 & 78.3 & $70(7 / 10)$ & 170 \\
\hline 45 & $\beta$-Cellobiose & C8-C9 & 75.9 & 78.3 & $70(7 / 10)$ & 131 \\
\hline 45 & $\beta$-Cellobiose & $\mathrm{C} 10-\mathrm{C} 9$ & 72.2 & 78.3 & $70(7 / 10)$ & 107 \\
\hline 45 & $\beta$-Cellobiose & $\mathrm{C} 12-\mathrm{C} 9$ & 63.3 & 78.3 & $70(7 / 10)$ & 93 \\
\hline 45 & $\beta$-Cellobiose & $\mathrm{C} 11-\mathrm{C} 10$ & 78.6 & 72.2 & $70(7 / 10)$ & 150 \\
\hline 45 & $\beta$-Cellobiose & C7-C11 & 104.3 & 78.6 & $70(7 / 10)$ & 170 \\
\hline 45 & $\beta$-Cellobiose & C8-C11 & 75.9 & 78.6 & $70(7 / 10)$ & 131 \\
\hline 45 & $\beta$-Cellobiose & $\mathrm{C} 10-\mathrm{C} 11$ & 72.2 & 78.6 & $70(7 / 10)$ & 107 \\
\hline 45 & $\beta$-Cellobiose & $\mathrm{C} 12-\mathrm{C} 11$ & 63.3 & 78.6 & $70(7 / 10)$ & 93 \\
\hline 45 & $\beta$-Cellobiose & C7-C12 & 104.3 & 63.3 & $70(7 / 10)$ & 171 \\
\hline 45 & $\beta$-Cellobiose & $\mathrm{C} 8-\mathrm{C} 12$ & 75.9 & 63.3 & $70(7 / 10)$ & 130 \\
\hline 45 & $\beta$-Cellobiose & C9-C12 & 78.3 & 63.3 & $70(7 / 10)$ & 148 \\
\hline 45 & $\beta$-Cellobiose & $\mathrm{C} 10-\mathrm{C} 12$ & 72.2 & 63.3 & $70(7 / 10)$ & 108 \\
\hline 45 & $\beta$-Cellobiose & $\mathrm{C} 11-\mathrm{C} 12$ & 78.6 & 63.3 & $70(7 / 10)$ & 148 \\
\hline 45 & $\beta$-Cellobiose & $\mathrm{C} 12-\mathrm{C} 7$ & 63.3 & 104.3 & $70(7 / 10)$ & 91 \\
\hline 45 & $\beta$-Cellobiose & $\mathrm{C} 12-\mathrm{C} 8$ & 63.3 & 75.9 & $70(7 / 10)$ & 87 \\
\hline 45 & $\beta$-Cellobiose & $\mathrm{C} 12-\mathrm{C} 9$ & 63.3 & 78.3 & $70(7 / 10)$ & 93 \\
\hline 45 & $\beta$-Cellobiose & $\mathrm{C} 12-\mathrm{C} 11$ & 63.3 & 78.6 & $70(7 / 10)$ & 93 \\
\hline 45 & $\beta$-Cellobiose & C7-C12 & 104.3 & 63.3 & $70(7 / 10)$ & 171 \\
\hline 45 & $\beta$-Cellobiose & $\mathrm{C} 8-\mathrm{C} 12$ & 75.9 & 63.3 & $70(7 / 10)$ & 130 \\
\hline 45 & $\beta$-Cellobiose & C9-C12 & 78.3 & 63.3 & $70(7 / 10)$ & 148 \\
\hline 45 & $\beta$-Cellobiose & $\mathrm{C} 10-\mathrm{C} 12$ & 72.2 & 63.3 & $70(7 / 10)$ & 108 \\
\hline 45 & $\beta$-Cellobiose & $\mathrm{C} 11-\mathrm{C} 12$ & 78.6 & 63.3 & $70(7 / 10)$ & 148 \\
\hline 46 & $\alpha$-Melibiose & $\mathrm{C} 4-\mathrm{C} 3$ & 72.3 & 75.8 & $40(4 / 10)$ & 106 \\
\hline 46 & $\alpha$-Melibiose & $\mathrm{C} 5-\mathrm{C} 3$ & 72 & 75.8 & $40(4 / 10)$ & 106 \\
\hline 46 & $\alpha$-Melibiose & $\mathrm{C} 6-\mathrm{C} 3$ & 68.5 & 75.8 & $40(4 / 10)$ & 99 \\
\hline 46 & $\alpha$-Melibiose & $\mathrm{C} 2-\mathrm{C} 4$ & 74.2 & 72.3 & $40(4 / 10)$ & 118 \\
\hline 46 & $\alpha$-Melibiose & $\mathrm{C} 2-\mathrm{C} 5$ & 74.2 & 72 & $40(4 / 10)$ & 118 \\
\hline
\end{tabular}




\begin{tabular}{ccccccc}
46 & $\alpha$-Melibiose & C5-C6 & 72 & 68.5 & $40(4 / 10)$ & $\mathbf{1 0 0}$ \\
46 & $\alpha$-Melibiose & C6-C3 & 68.7 & 75.8 & $40(4 / 10)$ & $\mathbf{9 9}$ \\
46 & $\alpha$-Melibiose & C6-C4 & 68.7 & 72.3 & $40(4 / 10)$ & $\mathbf{1 0 0}$ \\
46 & $\alpha$-Melibiose & C6-C5 & 68.7 & 72 & $40(4 / 10)$ & $\mathbf{1 0 0}$ \\
46 & $\alpha$-Melibiose & C3-C6 & 75.8 & 68.7 & $40(4 / 10)$ & $\mathbf{1 3 4}$ \\
\hline
\end{tabular}

Supplementary Table S4. Continued

\begin{tabular}{|c|c|c|c|c|c|c|}
\hline Metab. No. & Metabolites & Fragments & $\left.{ }^{13} \mathrm{C}[\mathrm{ppm}]\right]^{[\mathrm{a}]}$ & ${ }^{13} \mathrm{C}[\mathrm{ppm}]{ }^{[\mathrm{a}]}$ & $\begin{array}{c}\text { Evaluation } \\
(\mathrm{CH}- \\
\mathrm{CH})[\%]^{[\mathrm{b}]} \\
\end{array}$ & Peak No. ${ }^{[c]}$ \\
\hline 46 & $\alpha$-Melibiose & C5-C6 & 72 & 68.7 & $40(4 / 10)$ & 100 \\
\hline 46 & $\alpha$-Melibiose & C6-C3 & 68.8 & 75.8 & $40(4 / 10)$ & 99 \\
\hline 46 & $\alpha$-Melibiose & C6-C4 & 68.8 & 72.3 & $40(4 / 10)$ & 100 \\
\hline 46 & $\alpha$-Melibiose & C6-C5 & 68.8 & 72 & $40(4 / 10)$ & 100 \\
\hline 46 & $\alpha$-Melibiose & C3-C6 & 75.8 & 68.8 & $40(4 / 10)$ & 134 \\
\hline 46 & $\alpha$-Melibiose & C5-C6 & 72 & 68.8 & $40(4 / 10)$ & 100 \\
\hline 46 & $\alpha$-Melibiose & C11-C7 & 74.3 & 101 & $40(4 / 10)$ & 116 \\
\hline 46 & $\alpha$-Melibiose & $\mathrm{C} 11-\mathrm{C} 8$ & 74.3 & 71.2 & $40(4 / 10)$ & 121 \\
\hline 46 & $\alpha$-Melibiose & C11-C9 & 74.3 & 72.3 & $40(4 / 10)$ & 118 \\
\hline 46 & $\alpha$-Melibiose & $\mathrm{C} 11-\mathrm{C} 10$ & 74.3 & 72 & $40(4 / 10)$ & 118 \\
\hline 46 & $\alpha$-Melibiose & $\mathrm{C} 7-\mathrm{C} 11$ & 101 & 74.3 & $40(4 / 10)$ & 163 \\
\hline 46 & $\alpha$-Melibiose & $\mathrm{C} 11-\mathrm{C} 12$ & 74.3 & 63.9 & $40(4 / 10)$ & 120 \\
\hline 47 & Raffinose & $\mathrm{C} 5-\mathrm{C} 1$ & 74.3 & 101.1 & $38(5 / 13)$ & 116 \\
\hline 47 & Raffinose & $\mathrm{C} 5-\mathrm{C} 2$ & 74.3 & 71 & $38(5 / 13)$ & 121 \\
\hline 47 & Raffinose & $\mathrm{C} 6-\mathrm{C} 2$ & 63.7 & 71 & $38(5 / 13)$ & 94 \\
\hline 47 & Raffinose & $\mathrm{C} 5-\mathrm{C} 3$ & 74.3 & 72 & $38(5 / 13)$ & 118 \\
\hline 47 & Raffinose & C6-C3 & 63.7 & 72 & $38(5 / 13)$ & 95 \\
\hline 47 & Raffinose & $\mathrm{C} 5-\mathrm{C} 4$ & 74.3 & 71.9 & $38(5 / 13)$ & 118 \\
\hline 47 & Raffinose & C6-C4 & 63.7 & 71.9 & $38(5 / 13)$ & 95 \\
\hline 47 & Raffinose & $\mathrm{C} 1-\mathrm{C} 5$ & 101.1 & 74.3 & $38(5 / 13)$ & 163 \\
\hline 47 & Raffinose & C6-C5 & 63.7 & 74.3 & $38(5 / 13)$ & 97 \\
\hline 47 & Raffinose & $\mathrm{C} 2-\mathrm{C} 6$ & 71 & 63.7 & $38(5 / 13)$ & 103 \\
\hline 47 & Raffinose & $\mathrm{C} 5-\mathrm{C} 6$ & 74.3 & 63.7 & $38(5 / 13)$ & 120 \\
\hline 47 & Raffinose & $\mathrm{C} 9-\mathrm{C} 7$ & 72 & 68.4 & $38(5 / 13)$ & 100 \\
\hline 47 & Raffinose & $\mathrm{C} 12-\mathrm{C} 8$ & 94.6 & 74 & $38(5 / 13)$ & 161 \\
\hline 47 & Raffinose & $\mathrm{C} 8-\mathrm{C} 9$ & 74 & 72 & $38(5 / 13)$ & 118 \\
\hline 47 & Raffinose & $\mathrm{C} 11-\mathrm{C} 9$ & 73.7 & 72 & $38(5 / 13)$ & 118 \\
\hline 47 & Raffinose & $\mathrm{C} 7-\mathrm{C} 10$ & 68.4 & 75.7 & $38(5 / 13)$ & 99 \\
\hline 47 & Raffinose & C9-C10 & 72 & 75.7 & $38(5 / 13)$ & 106 \\
\hline 47 & Raffinose & $\mathrm{C} 12-\mathrm{C} 11$ & 94.6 & 73.7 & $38(5 / 13)$ & 161 \\
\hline 47 & Raffinose & C9-C7 & 72 & 68.1 & $38(5 / 13)$ & 100 \\
\hline 47 & Raffinose & $\mathrm{C} 7-\mathrm{C} 10$ & 68.1 & 75.7 & $38(5 / 13)$ & 99 \\
\hline 48 & $\alpha$-D-Glucose 6-phosphate & $\mathrm{C} 4-\mathrm{C} 3$ & 72 & 75.4 & $40(2 / 5)$ & 106 \\
\hline 48 & $\alpha$-D-Glucose 6-phosphate & $\mathrm{C} 2-\mathrm{C} 4$ & 74.4 & 72 & $40(2 / 5)$ & 118 \\
\hline 48 & $\alpha$-D-Glucose 6-phosphate & $\mathrm{C} 3-\mathrm{C} 4$ & 75.4 & 72 & $40(2 / 5)$ & 127 \\
\hline 48 & $\alpha$-D-Glucose 6-phosphate & $\mathrm{C} 5-\mathrm{C} 4$ & 73.8 & 72 & $40(2 / 5)$ & 118 \\
\hline 48 & $\alpha$-D-Glucose 6-phosphate & $\mathrm{C} 1-\mathrm{C} 5$ & 94.9 & 73.8 & $40(2 / 5)$ & 161 \\
\hline 48 & $\alpha$-D-Glucose 6-phosphate & $\mathrm{C} 4-\mathrm{C} 2$ & 72 & 77 & $40(2 / 5)$ & 105 \\
\hline 49 & $\beta$-Melibiose & $\mathrm{C} 2-\mathrm{C} 1$ & 76.6 & 98.9 & $40(4 / 10)$ & 138 \\
\hline 49 & $\beta$-Melibiose & $\mathrm{C} 5-\mathrm{C} 1$ & 77 & 98.9 & $40(4 / 10)$ & 138 \\
\hline 49 & $\beta$-Melibiose & $\mathrm{C} 6-\mathrm{C} 2$ & 68.5 & 76.6 & $40(4 / 10)$ & 99 \\
\hline
\end{tabular}




\begin{tabular}{|c|c|c|c|c|c|c|}
\hline 49 & $\beta$-Melibiose & $\mathrm{C} 4-\mathrm{C} 3$ & 72.3 & 78.8 & $40(4 / 10)$ & 107 \\
\hline 49 & $\beta$-Melibiose & $\mathrm{C} 6-\mathrm{C} 2$ & 68.7 & 76.6 & $40(4 / 10)$ & 99 \\
\hline 49 & $\beta$-Melibiose & $\mathrm{C} 2-\mathrm{C} 4$ & 76.6 & 72.3 & $40(4 / 10)$ & 137 \\
\hline 49 & $\beta$-Melibiose & C6-C4 & 68.7 & 72.3 & $40(4 / 10)$ & 100 \\
\hline 49 & $\beta$-Melibiose & C6-C2 & 68.8 & 76.6 & $40(4 / 10)$ & 99 \\
\hline 49 & $\beta$-Melibiose & C6-C4 & 68.8 & 72.3 & $40(4 / 10)$ & 100 \\
\hline
\end{tabular}


Supplementary Table S4. Continued

\begin{tabular}{ccccccc} 
Metab. No. & Metabolites & Fragments & ${ }^{13} \mathrm{C}[\mathrm{ppm}]{ }^{[\mathrm{a}]}$ & ${ }^{13} \mathrm{C}[\mathrm{ppm}]^{[\mathrm{a}]}$ & $\begin{array}{c}\text { Evaluation } \\
(\mathrm{CH}- \\
\mathrm{CH})[\%]^{[\mathrm{b}]}\end{array}$ & Peak No. $^{[\mathrm{cc}]}$ \\
\hline 49 & $\beta$-Melibiose & $\mathrm{C} 11-\mathrm{C} 7$ & 74.3 & 101 & $40(4 / 10)$ & $\mathbf{1 1 6}$ \\
49 & $\beta$-Melibiose & $\mathrm{C} 11-\mathrm{C} 8$ & 74.3 & 71.2 & $40(4 / 10)$ & $\mathbf{1 2 1}$ \\
49 & $\beta$-Melibiose & $\mathrm{C} 11-\mathrm{C} 9$ & 74.3 & 72.8 & $40(4 / 10)$ & $\mathbf{1 1 8}$ \\
49 & $\beta$-Melibiose & $\mathrm{C} 11-\mathrm{C} 10$ & 74.3 & 72 & $40(4 / 10)$ & $\mathbf{1 1 8}$ \\
49 & $\beta$-Melibiose & $\mathrm{C} 7-\mathrm{C} 11$ & 101 & 74.3 & $40(4 / 10)$ & $\mathbf{1 6 3}$ \\
49 & $\beta$-Melibiose & $\mathrm{C} 11-\mathrm{C} 12$ & 74.3 & 63.9 & $40(4 / 10)$ & $\mathbf{1 2 0}$ \\
\hline
\end{tabular}


Supplementary Table S5. List of calculated RMSD values between the experimental and theoretical chemical shifts of compounds in $C$. brachypus for which $100 \%$ correlation signals were confirmed in Table S3 and Table S4.

\begin{tabular}{|c|c|c|c|c|c|c|c|c|}
\hline \multirow{2}{*}{ Metabolites } & \multicolumn{2}{|c|}{ Most stable structure } & \multicolumn{2}{|c|}{ Ionization structure } & \multicolumn{2}{|c|}{ Boltzmann distribution } & \multicolumn{2}{|c|}{ Regression } \\
\hline & ${ }^{1} \mathrm{H}$ & ${ }^{13} \mathrm{C}$ & ${ }^{1} \mathrm{H}$ & ${ }^{13} \mathrm{C}$ & ${ }^{1} \mathrm{H}$ & ${ }^{13} \mathrm{C}$ & ${ }^{1} \mathrm{H}$ & ${ }^{13} \mathrm{C}$ \\
\hline Citrulline & 0.188 & 6.700 & 0.250 & 8.458 & 0.196 & 6.398 & 0.238 & 3.052 \\
\hline L-Alanine & 0.121 & 5.237 & 0.157 & 6.666 & 0.120 & 5.252 & 0.186 & 1.632 \\
\hline L-Arginine & 0.195 & 6.713 & 0.349 & 12.438 & 0.191 & 6.181 & 0.245 & 3.073 \\
\hline L-Aspartic acid & 0.111 & 4.143 & 0.495 & 5.341 & 0.112 & 4.148 & 0.126 & 0.419 \\
\hline L-Glutamic acid & 0.440 & 4.467 & 0.857 & 3.052 & 0.040 & 4.880 & 0.450 & 2.687 \\
\hline L-Leucine & 0.170 & 4.332 & 0.127 & 5.080 & 0.167 & 4.351 & 0.202 & 2.573 \\
\hline L-Threonine & 0.497 & 6.062 & 0.483 & 5.881 & 0.484 & 5.676 & 0.569 & 2.527 \\
\hline 3-Phosphoglyceric acid & 0.385 & 8.913 & 0.338 & 5.865 & 0.556 & 8.725 & 0.242 & 7.233 \\
\hline Acetic acid & 0.234 & 2.786 & 0.133 & 2.524 & 0.235 & 2.741 & 0.184 & 6.687 \\
\hline Formic acid & 0.322 & 1.279 & 0.882 & 4.238 & 0.269 & 1.293 & 0.612 & 6.185 \\
\hline Methylmalonic acid & 0.408 & 5.132 & 0.202 & 6.176 & 0.383 & 4.044 & 0.345 & 6.559 \\
\hline Phosphoenolpyruvic acid & 0.235 & 1.452 & 0.405 & 11.940 & 0.304 & 1.971 & 0.052 & 3.001 \\
\hline Succinate & 0.316 & 4.053 & 0.170 & 9.286 & 0.339 & 2.401 & 0.243 & 8.018 \\
\hline$\alpha$-D-Glucose & 0.273 & 6.316 & - & - & 0.241 & 6.484 & 0.208 & 2.407 \\
\hline$\beta$-D-Glucose & 0.196 & 5.003 & - & - & 0.368 & 6.727 & 0.117 & 0.975 \\
\hline$\beta$-D-Glucuronate & 0.580 & 4.270 & 0.374 & 5.238 & 0.594 & 4.187 & 0.447 & 3.655 \\
\hline Methanol & 0.418 & 5.558 & - & - & - & - & 0.302 & 1.426 \\
\hline Trimethylamine & 0.617 & 3.503 & - & - & - & - & 0.672 & 0.587 \\
\hline
\end{tabular}


Supplementary Table S6. Experimental solubility data for 18 compounds in water obtained from PubChem, HMDB, and Santa Cruz Biotechnology databases. Also, the aqueous solubility was calculated by using ALOGPS 2.1.

\begin{tabular}{crrr} 
& \multicolumn{3}{c}{ Solubility in water $[\mathrm{g} / \mathrm{L}]$} \\
& Exp. & \multicolumn{2}{c}{ Calc. } \\
\hline Metabolites & 200 & $*$ & 21.8 \\
Citrulline & 164 & $* *$ & 447 \\
L-Alanine & 182 & $* *$ & 7.59 \\
L-Aspartic acid & 5.39 & $* *$ & 142 \\
L-Glutamic acid & 8.88 & $* *$ & 80.6 \\
L-Leucine & 21.5 & $* *$ & 69.8 \\
L-Threonine & 97 & $* *$ & 477 \\
3-Phosphoglyceric acid & 50 & & 21 \\
Acetic acid & 1000 & $* *$ & 323 \\
Formic acid & 1000 & $* *$ & 477 \\
Methylmalonic acid & 679 & $* *$ & 149 \\
Phosphoenolpyruvic acid & 100 & & 13.2 \\
Succinate & 83.2 & $* *$ & 211 \\
$\alpha$-D-Glucose & 1200 & & 782 \\
$\beta$-D-Glucose & 1200 & & 782 \\
$\beta$-D-Glucuronate & 485 & & 295 \\
Methanol & 1000 & $* *$ & 519 \\
Trimethylamine & 890 & $* * *$ & 654 \\
\hline$*$ Experiment at $20^{\circ} \mathrm{C} ; * * 2{ }^{\circ} \mathrm{C} ; * * 30^{\circ} \mathrm{C}$ &
\end{tabular}


Supplementary Table S7. List of calculated RMSD values between the experimental and theoretical chemical shifts of some compounds to test the effect of water.

\begin{tabular}{ccccc} 
Metabolites & \multicolumn{2}{c}{ PCM method } & \multicolumn{2}{c}{ PCM + added water } \\
& ${ }^{1} \mathrm{H}$ & ${ }^{13} \mathrm{C}$ & ${ }^{1} \mathrm{H}$ & ${ }^{13} \mathrm{C}$ \\
\hline Formic acid & 0.322 & 1.279 & 0.302 & 2.645 \\
Fumaric acid & 0.786 & 5.242 & 0.671 & 6.174 \\
L-Serine & 0.299 & 8.103 & 0.259 & 11.339 \\
L-Glutamic acid & 0.440 & 4.467 & 0.145 & 6.409 \\
$\beta$-D-Glucose & 0.196 & 5.003 & 0.145 & 7.175 \\
\hline
\end{tabular}


Supplementary Table S8. The annotation list for Q-C correlations of C. brachypus by database searching. These peaks were also detected by covariance processing using ${ }^{13} \mathrm{C}-{ }^{13} \mathrm{C}$ TOCSY.

\begin{tabular}{|c|c|c|c|}
\hline Metabolites & Fragments & ${ }^{13} \mathrm{C}[\mathrm{ppm}]$ & ${ }^{13} \mathrm{C}[\mathrm{ppm}]$ \\
\hline 2-Cyanoacetamide & $\mathrm{C} 2-\mathrm{Q} 1$ & 25.7 & 168.3 \\
\hline 2-Hydroxybutyric acid & C3-Q1 & 27.3 & 178.3 \\
\hline 3-Hydroxybutyric acid & C4-Q1 & 24.5 & 182.1 \\
\hline$\beta$-Alanine & $\mathrm{C} 2-\mathrm{Q} 1$ & 35.1 & 179.5 \\
\hline$\beta$-Alanine & C3-Q1 & 37.8 & 180.1 \\
\hline Citric acid & Q4-Q1 & 181.3 & 184.8 \\
\hline DL-Glutamate & C4-Q1 & 56.0 & 183.2 \\
\hline DL-Glutamate & $\mathrm{C} 2-\mathrm{Q} 5$ & 35.1 & 179.5 \\
\hline Ethylmethylacetic acid & C3-Q1 & 27.0 & 183.8 \\
\hline$\gamma$-Aminobutyric acid & C3-Q1 & 27.0 & 183.8 \\
\hline$\gamma$-Butyrolactone & $\mathrm{C} 2-\mathrm{Q} 1$ & 27.3 & 178.3 \\
\hline Gentisic acid & C3-Q1 & 112.8 & 173.6 \\
\hline Gluconolactone & C4-Q1 & 75.4 & 181.4 \\
\hline Homo-L-arginine & C4-Q1 & 23.3 & 177.8 \\
\hline Isobutyric acid & C3-Q1 & 19.2 & 184.7 \\
\hline L-Glutamine & C3-Q1 & 27.8 & 178.2 \\
\hline L-Glutamine & $\mathrm{C} 5-\mathrm{Q} 2$ & 34.0 & 176.5 \\
\hline L-Isoleucine & $\mathrm{C} 5-\mathrm{Q} 1$ & 15.8 & 173.6 \\
\hline L-Leucine & C6-Q1 & 23.5 & 177.7 \\
\hline L-Leucine & C5-Q1 & 24.2 & 177.7 \\
\hline Maltol & $\mathrm{C} 2-\mathrm{Q} 3$ & 112.8 & 173.6 \\
\hline Methylglutaric acid & C3-Q1 & 27.3 & 178.3 \\
\hline Methylglutaric acid & C4-Q1 & 19.2 & 179.6 \\
\hline$N$-Acetyl-L-aspartic acid & $\mathrm{C} 2-\mathrm{Q} 1$ & 55.6 & 182.3 \\
\hline Niacinamide & $\mathrm{C} 2-\mathrm{Q} 1$ & 132.8 & 173.6 \\
\hline Oxoglutaric acid & $\mathrm{C} 2-\mathrm{Q} 1$ & 39.1 & 184.9 \\
\hline Pyrrolidonecarboxylic acid & C3-Q1 & 24.5 & 182.1 \\
\hline Pyrrolidonecarboxylic acid & C4-Q1 & 56.0 & 183.2 \\
\hline
\end{tabular}




\section{References}

(1) Ito, K., Sakata, K., Date, Y., and Kikuchi, J. (2014) Integrated analysis of seaweed components during seasonal fluctuation by data mining across heterogeneous chemical measurements with network visualization. Anal. Chem. 86, 1098-1105.

(2) Wei, F., Ito, K., Sakata, K., Date, Y., and Kikuchi, J. (2015) Pretreatment and integrated analysis of spectral data reveal seaweed similarities based on chemical diversity. Anal. Chem. 87, 2819-2826.

(3) Schmieder, P., Stern, A. S., Wagner, G., and Hoch, J. C. (1993) Application of nonlinear sampling schemes to COSY-type spectra. J. Biomol. NMR 3, 569-576.

(4) Schmieder, P., Stern, A. S., Wagner, G., and Hoch, J. C. (1994) Improved resolution in triple-resonance spectra by nonlinear sampling in the constant-time domain. J. Biomol. NMR 4, 483-490.

(5) Kazimierczuk, K., and Orekhov, V. Y. (2011) Accelerated NMR spectroscopy by using compressed sensing. Angew. Chem. Int. Ed. 50, 55565559.

(6) Martineau, E., Akoka, S., Boisseau, R., Delanoue, B., and Giraudeau, P. (2013) Fast quantitative ${ }^{1} \mathrm{H}-{ }^{13} \mathrm{C}$ two-dimensional NMR with very high precision. Anal. Chem. 85, 4777-4783.

(7) Le Guennec, A., Giraudeau, P., and Caldarelli, S. (2014) Evaluation of fast 2D NMR for metabolomics. Anal. Chem. 86, 5946-5954.

(8) Ikeya, T., Sasaki, A., Sakakibara, D., Shigemitsu, Y., Hamatsu, J., Hanashima, T., Mishima, M., Yoshimasu, M., Hayashi, N., Mikawa, T., Nietlispach, D., Wälchli, M., Smith, B. O., Shirakawa, M., Güntert, P., and Ito, Y. (2010) NMR protein structure determination in living E. coli cells using nonlinear sampling. Nat. Protoc. 5, 1051-1060.

(9) Inomata, K., Ohno, A., Tochio, H., Isogai, S., Tenno, T., Nakase, I., Takeuchi, T., Futaki, S., Ito, Y., Hiroaki, H., and Shirakawa, M. (2009) High-resolution multi-dimensional NMR spectroscopy of proteins in human cells. Nature 458, 106-109.

(10) Chikayama, E., Sekiyama, Y., Okamoto, M., Nakanishi, Y., Tsuboi, Y., Akiyama, K., Saito, K., Shinozaki, K., and Kikuchi, J. (2010) Statistical indices for simultaneous large-scale metabolite detections for a single NMR spectrum. Anal. Chem. 82, 1653-1658.

(11) Ulrich, E. L., Akutsu, H., Doreleijers, J. F., Harano, Y., Ioannidis, Y. E., Lin, J., Livny, M., Mading, S., Maziuk, D., Miller, Z., Nakatani, E., Schulte, C. F., Tolmie, D. E., Wenger, R. K., Yao, H., and Markley, J. L. (2008) BioMagResBank. Nucleic Acids Res. 36, D402-D408.

(12) Wishart, D. S., Jewison, T., Guo, A. C., Wilson, M., Knox, C., Liu, Y., Djoumbou, Y., Mandal, R., Aziat, F., Dong, E., Bouatra, S., Sinelnikov, I., Arndt, D., Xia, J., Liu, P., Yallou, F., Bjorndahl, T., Perez-Pineiro, R., Eisner, R., Allen, F., Neveu, V., Greiner, R., and Scalbert, A. (2013) HMDB 3.0 - The human metabolome database in 2013. Nucleic Acids Res. 41, D801-D807.

(13) Bingol, K., Zhang, F., Bruschweiler-Li, L., and Brüschweiler, R. (2012) TOCCATA: A customized carbon total correlation spectroscopy NMR metabolomics database. Anal. Chem. 84, 9395-9401.

(14) Bingol, K., Li, D.-W., Bruschweiler-Li, L., Cabrera, O. A., Megraw, T., Zhang, F., and Brüschweiler, R. (2015) Unified and isomer-specific NMR metabolomics database for the accurate analysis of ${ }^{13} \mathrm{C}-{ }^{1} \mathrm{H}$ HSQC spectra. ACS Chem. Biol. 10, 452-459.

(15) Levenshtein, V. (1966) Binary codes capable of correcting deletions, insertions, and reversals. Sov. Phys. Dokl. 10, 707-710.

(16) Bremser, W. (1978) Hose - a novel substructure code. Anal. Chim. Acta 103, 355-365.

(17) Wagener, M., and Gasteiger, J. (1994) The determination of maximum common substructures by a genetic algorithm: Application in synthesis design and for the structural analysis of biological activity. Angew. Chem. Int. Ed. 33, 1189-1192.

(18) Steinbeck, C., Han, Y., Kuhn, S., Horlacher, O., Luttmann, E., and Willighagen, E. (2003) The Chemistry Development Kit (CDK): An open-source Java library for chemo- and bioinformatics. J. Chem. Inf. Comput. Sci. 43, 493-500.

(19) Cheeseman, J. R., Trucks, G. W., Keith, T. A., and Frisch, M. J. (1996) A comparison of models for calculating nuclear magnetic resonance shielding tensors. J. Chem. Phys. 104, 5497-5509.

(20) Becke, A. D. (1993) Density-functional thermochemistry. III. The role of exact exchange. J. Chem. Phys. 98, 5648-5652.

(21) Wiberg, K. B. (2004) Basis set effects on calculated geometries: 6-311++ G** vs. aug-cc-pVDZ. J. Comput. Chem. 25, $1342-1346$.

(22) Tomasi, J., Mennucci, B., and Cammi, R. (2005) Quantum mechanical continuum solvation models. Chem. Rev. 105, $2999-3094$.

(23) Dračínský, M., Buděšínský, M., Warżajtis, B., and Rychlewska, U. (2012) Solution and solid-state effects on NMR chemical shifts in sesquiterpene lactones: NMR, X-ray, and theoretical methods. J. Phys. Chem. A 116, 680-688.

(24) Sarotti, A. M., and Pellegrinet, S. C. (2009) A multi-standard approach for GIAO ${ }^{13}$ C NMR calculations. J. Org. Chem. 74, 7254-7260.

(25) Barone, G., Duca, D., Silvestri, A., Gomez-Paloma, L., Riccio, R., and Bifulco, G. (2002) Determination of the relative stereochemistry of flexible organic compounds by ab initio methods: Conformational analysis and Boltzmann-averaged GIAO ${ }^{13} \mathrm{C}$ NMR chemical shifts. Chem.-Eur. J. 8, 3240-3245.

(26) Efroymson, M. A. (1960) Multiple regression analysis. In Mathematical Methods for Digital Computers. Ralston, A., and Wilf, H. S., Eds. Wiley: New York, pp. 191-203.

(27) Heskes, T. (1997) Practical confidence and prediction intervals. In Advances in Neural Information Processing Systems 9: Proceedings of the 1996 Conference. Mozer, M. C., Jordan, M. I., and Petsche, T. (Eds.) MIT Press: Cambridge, MA, pp. 176-182.

(28) Tetko, I. V., Tanchuk, V. Y., Kasheva, T. N., and Villa, A. E. (2001) Estimation of aqueous solubility of chemical compounds using E-state indices. J. Chem. Inf. Comput. Sci. 41, 1488-1493.

(29) Mulder, F. A. A., and Filatov, M. (2010) NMR chemical shift data and ab initio shielding calculations: Emerging tools for protein structure determination. Chem. Soc. Rev. 39, 578-590. 